$1-1-2006$

\title{
American Indians, Crime, and the Law
}

Kevin Washburn

University of New Mexico - School of Law

Follow this and additional works at: https://digitalrepository.unm.edu/law_facultyscholarship

Part of the Indian and Aboriginal Law Commons

\section{Recommended Citation}

Kevin Washburn, American Indians, Crime, and the Law, 104 Michigan Law Review 709 (2006).

Available at: https://digitalrepository.unm.edu/law_facultyscholarship/497

This Article is brought to you for free and open access by the UNM School of Law at UNM Digital Repository. It has been accepted for inclusion in Faculty Scholarship by an authorized administrator of UNM Digital Repository. For more information, please contact amywinter@unm.edu, Isloane@salud.unm.edu, sarahrk@unm.edu.

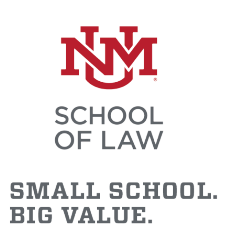

BIG VALUE. 


\title{
AMERICAN INDIANS, CRIME, AND THE LAW
}

\author{
Kevin K. Washburn*
}

TABle of Contents

INTRODUCTION

I. The Modern Structure and Process of

Indian Country CRiminal Justice .......................................715

A. A Legal Description of the Indian Country Regime .......... 715

B. A Practical, Critical Description of the Process of an Indian Country Case ..................................................... 718

II. Federal Prosecutors in Indian Country ........................ 725

A. Community Values and the Foundation of Prosecutorial Discretion and Prosecutorial Accountability ................... 725

B. The Federal Prosecutor in Indian Country ...................... 729

1. The Prosecutor as Representative of

the Community.......................................................... 729

2. The Accountability Problem..................................... 730

3. Federal Prosecutors and the Cavalry Effect............... 735

4. Obstacles to Tribal Governance and

Self-Determination....................................................... 738

C. Concluding Thoughts about Federal Prosecutors.............740

III. JuRIES AND JURY Composirion IN INDIAN COUNTRY ............ 741

A. The Centrality of the Jury in American

Criminal Justice

B. Representative Juries and Anti-Discrimination in

Jury Composition ........................................................... 745

C. Underrepresentation of Native Americans on

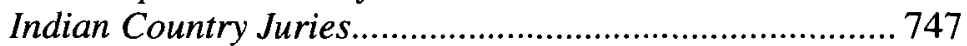

D. Legal Challenges..........................................................751

* Associate Professor, University of Minnesota Law School. -Ed. For helpful comments, suggestions, and support, the author wishes to thank James Anaya, Norman Bay, Bethany Berger, Kathleen Bliss, the Hon. William C. Canby, Jr., Chris Chaney, Guy Charles, Gavin Clarkson, John DiPippa, Barry Feld, Richard Frase, Steve Gunn, Sidney Harring, Angela Harris, Tom Heffelfinger, Joan Howland, Alex M. Johnson, Sarah Krakoff, Stacy Leeds, Toni Massaro, Robert McCampbell, Richard Monette, Nell Newton, William Pizzi, Robert Odawi Porter, Jonathan Simon, Alex Tallchief Skibine, Joseph Singer, Rennard Strickland, Scott Taylor, Michael Tonry, Charles Weisselberg, Charles Wilkinson, the participants at law school lectures, formal or informal workshops, or colloquia at the Universities of Arizona, California-Berkeley, Colorado, Michigan, Minnesota, and New Mexico, the participants at the Federal Bar Association's Annual Indian Law conferences in Albuquerque in April 2004 and Washington, D.C. in September 2004, and the participants at the Indian Country Law Conference sponsored by Syracuse University's Center for Indigenous Law Governance and Citizenship in Miami, Florida, in February 2005. The author appreciates the hard work of research assistants Rjay Brunkow, Dennis Puzz, Chloe Thompson, Sara Van Norman, and Michael Reif. Special thanks to Phil Frickey, Carole Goldberg, Frank Zimring, and, as always, Libby Rodke Washbum. 
E. A Critique of Jury Composition Cases in Indian Country ................................................................. 755

1. Representativeness and a Jury of One's Peers............ 755

2. Considering the Indian Law Context of These Cases 756

3. Focusing on "The Community"................................ 757

4. Practical Effects of These Errors................................ 762

IV. Public Access, Venue, and Public Trials ........................ 764

A. Rights of Public Access to Criminal Trials........................ 766

1. The Source and Rationale for the Right to

Public Trials and Public Access ................................. 766

2. Public Access and Indian Country Defendants .......... 768

3. Public Access and Indian Country Communities........ 770

4. Public Trials and Self-Government........................... 772

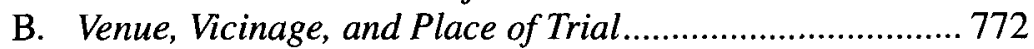

V. A FRAMEWORK FOR ANALYSIS OF REFORM............................. 775

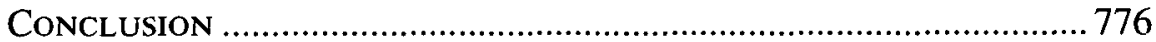

\section{INTRODUCTION}

When a Navajo tribal member commits a serious felony against another Navajo on the remote Navajo Indian Reservation, the crime sets in motion not a tribal criminal investigation and tribal court proceeding, but a federal investigation and federal court proceeding under the federal Major Crimes Act.' For trial, the Navajo defendant, the Navajo victim, and the witnesses (all of whom are also likely to be Navajo) will be summoned to a federal district court far away from the reservation and the specific community where the crime occurred. Unlike a felony involving only non-Indians, which would be routinely adjudicated at the local county or district courthouse, the Navajo felony will be tried in a distant federal court in Phoenix, Salt Lake City, or Albuquerque. ${ }^{2}$

The federal court operates in a language that is foreign to many Navajos; thus the Navajo defendants, victims, and witnesses may require interpreters to translate the proceedings. Neither the judge, the court reporter, the prosecutor, $^{3}$ the court security officers, the deputy marshals, nor the defense

1. 18 U.S.C. $\$ 1153(2000)$. Even if tribal police investigate the offense, the tribal police may very well be acting with federal funding, administering a federal responsibility, and acting, in effect, as federal agents. See, e.g., Indian Law Enforcement Reform Act, Pub. L. No. 101-379, 104 Stat. 473 (1990) (codified primarily at 25 U.S.C. $\$ \S 2801-2809$ (2000)).

2. Depending in part on the precise location where the crime occurred and in part on the pleasure of the federal judge assigned to hear the matter, such a case might also be tried in Prescott, Arizona, or Santa Fe, New Mexico, though these locations are also substantially distant from the Navajo reservation.

3. The Navajo Nation is the second largest Indian tribe in the United States. It has a legal culture so well established that it has long had its own bar examination and a court system with numerous district courts and a supreme court that, together, hear tens of thousands civil and misdemeanor cases each year. See Harvard LaW Sch., Navajo Nation Courts (2004), 
attorney or investigator are likely to be Navajo or even understand or speak the Navajo language. Perhaps even more importantly, the federal jury that hears the evidence is unlikely to include a Navajo, or even an Indian, or any other member of the community where the crime occurred. ${ }^{4}$

While the Navajo Nation provides a compelling example of such alienation because it ranges across three states and is inhabited by more than 180,000 people in hundreds of distinct Indian communities, this federal criminal justice regime spans more than one hundred Indian reservations across the United States and involves thousands of federal cases opened each year within "Indian country" as that term is defined by federal law. Thus, similar circumstances can be described for many other Indian tribes and their reservations, such as the Jicarilla Apache in northern New Mexico, the Hualapi who live adjacent to the Grand Canyon in Arizona, the Red Lake Chippewa in northern Minnesota, or the various Chippewa and Potawatomi tribes in Michigan's upper peninsula.

Serious practical problems arise by virtue of the vast distances between some Indian reservations and the federal courts that serve them. Consider, for example, the challenge facing a victim or witness from the Red Lake Band of Ojibwe Reservation near the Canadian border in northern Minnesota who may be required by federal summons to travel 250 miles or more of back roads and highways to reach federal court in St. Paul or Minneapolis, Minnesota. ${ }^{6}$ While such distances would be daunting to anyone, residents of Indian reservations (and certainly victims and witnesses to violent crime) tend to have incomes well below the poverty level.' It is fair to assume that most reservation residents drive vehicles consistent with their respective income levels. ${ }^{8}$ Indeed, the "Indian car" has become nearly as

http://hapahie.com/courts.cfm. Yet not one of the dozens of federal prosecutors who prosecute all of the federal felonies from the Navajo reservation is a Navajo tribal member.

4. See, e.g., United States v. Footracer, 189 F.3d 1058 (9th Cir. 1999) (holding that the transfer of a case to a district court division with a much lower percentage of American Indians did not deprive defendant of a jury representing a fair cross-section of the community); United States $v$. Etsitty, 130 F.3d 420, 425-26 (9th Cir. 1997) (finding no evidence of discriminatory jury selection in this case but noting in dicta that the systematic transfer of cases to district court divisions with lower percentages of American Indians might result in the discriminatory exclusion of American Indians); United States v. Turcotte, 558 F.2d 893, 895 (8th Cir. 1977) (noting that there were no American Indians on the jury, although defendant failed to prove discrimination in the jury selection system).

5. See 18 U.S.C. $\S 1151(2000)$.

6. The distance from the Red Lake Reservation to Minneapolis is approximately 250 miles and might take nearly six hours even with good road conditions. Similarly, the Fort Peck Reservation is nearly 300 miles from the federal courts in either Great Falls or Billings, and both drives could easily take six hours in good weather. See Robert N. Clinton et al., AMErican Indian LaW: Native Nations and THE Federal. SySTEM 657-62 (4th ed. 2004).

7. Low income is correlated with a high rate of violent crime victimization for American Indians. Steven W. Perry, U.S. Dep't of Justice, American Indians and Crime: A BJS StatisTICAL Profile, 1992-2002, at 5 (2004), available at http://www.ojp.usdoj.gov/bjs/pub/pdf/ aic02.pdf; see also LaWrence A. Greenfeld \& Steven K. Smith, U.S. Dep't of Justice, AMERICAN INDIANS \& CRIME 5 (1999), available at http:/www.ojp.usdoj.gov/bjs/pub/pdf/aic.pdf.

8. In $1999,41.5 \%$ of the residents of the Navajo Nation, for example, had household incomes of less than $\$ 14,999$. U.S. Census Bureau, Profile of Selected Economic 
fabled today as the Plains Indian pony was in the past, but for vastly different reasons.

In sum, a witness in an Indian country case may be facing a five-hour or longer drive in an untrustworthy vehicle in a northern winter with nothing to look forward to but being forced to speak in public in front of a large group of non-Indian strangers, or being forced to endure a painful cross-examination in which her motives and perhaps her character will be questioned. ${ }^{10}$ Consider also the unfortunate federal prosecutor ${ }^{11}$ or defense attorney: a harried trial attorney working hard to marshal the evidence in a criminal case while nervously looking out the window of the federal courthouse (at falling snow in Minneapolis in winter or the scorching desert terrain in Arizona in the summer time) and desperately hoping that her witnesses appear on time to testify. ${ }^{12}$

As a result of a series of federal statutes, felony criminal justice is primarily a federal responsibility on hundreds of Indian reservations in the Southeast, the Midwest, and throughout the western United States. ${ }^{13}$ Though the problems identified above are simple, practical obstacles to effective

Characteristics: Navajo Nation Reservation and Off-Reservation Trust Land 3 (2000), available at http://censtats.census.gov/data/US/2502430.pdf. Likewise, 32.3\% of residents of the Fort Peck Reservation and 34.6\% of residents of the Red Lake Reservation eamed household incomes of less than $\$ 14,999$ in 1999. U.S. Census Bureau, Profile of Selected Economic Characteristics: 2000: Geographic Area: Fort Peck Reservation and Off-Reservation TRUST LAND 3 (2000), available at http://centstats.census.gov/data/US/2501250.pdf.

9. The phrase "Indian car" has become a term of art in Indian country, and was immortalized in a song by the same name by Bois Forte Chippewa recording artist Keith Secola and his Wild Band of Indians. Keith Secola and the Wild Band of Indians, Indian Car, on Circle (Normal/Akina Records 1992). In the song, Secola describes the stereotypical Indian car: "My car is dented, the radiator steams / Head light don't work, radio can scream / Got a sticker, says "Indian power" / On my bumper, holds my car together." The 1999 Miramax film release Smoke Signals features an Indian car that can only drive in reverse, derived from a Sherman Alexie story. SHERMAN Alexie, The Lone Ranger and Tonto Fistfight in Heaven 156 (HarperPerennial 1994) (1993); SMOKE Signals (Miramax 1998). In sum, the Indian car is generally considered far less reliable than the Indian pony of the nineteenth century.

10. American Indians age twelve and over are victims of rape and sexual assault at a rate nearly four times that of all races (seven Indian victims per 1000, compared to two victims per 1000 for all races). GREENFELD \& SMITH, supra note 7, at 3.

11. As a practical matter, federal prosecutors in such cases rely heavily on victim/witness coordinators, often tribal members themselves, who work in the United States Attorneys' Offices. Victim/witness coordinators provide a host of duties to prosecutors and crime victims. One of the most basic is to ensure that Indian victims and witnesses are provided transportation and accommodations so that they can appear for trial. The victim/witness coordinators are vital to the federal prosecutors, and most cases that go to trial would not be successful without their hard work, their careful logistical planning, and the supportive bond they form with the Indian victims and witnesses. For a description of the role these employees play, see generally U.S DEP'T OF JUSTICE, VICTIMS and Witnesses: Understanding Your Rights and the Federal Court System (2002), available at http://www.justice.gov/usao/alm/LECC/VW_Rights.htm.

12. Larry EchoHawk, Child Sexual Abuse in Indian Country: Is the Guardian Keeping in Mind the Seventh Generation?, 5 N.Y.U. J. LEGIS. \& PUB. POL'Y 83, 99 (2001) ("[T]ravel time [in federal Indian country cases] is often three or four hours or more. When witnesses have to travel far to give testimony, they sometimes do not show up.").

13. On some reservations in so-called Public Law 280 states, this responsibility is a state and local one. See generally Carol E. Goldberg, Public Law 280: The Limits of State Jurisdiction over Reservation Indians, 22 UCLA L. Rev. 535 (1975). 
criminal justice, they may represent problems that are far more serious. In the United States, criminal justice is an inherently local activity as a matter of constitutional design; American criminal justice systems are carefully designed to empower local communities to solve internal problems and to restore peace and harmony in the community. Viewed in this light, many of the practical problems outlined above, and more serious ones discussed below, may represent violations of fundamental constitutional norms. In short, federal justice in Indian country simply may not accord with many of the basic legal principles that guide American courts, prosecutors, and law enforcement officials.

Consider some of the most obvious questions raised by a federal Indian country prosecution: Does an Indian defendant receive a trial by a jury of his peers when he faces a federal jury in a distant city composed of nonIndians who are foreign to the Indian community, who may very well speak a different language and who are subject to a different set of laws and a different process for adjudicating them? Does an Indian community have a voice in issues of public safety when its local felonies are prosecuted, defended, and adjudicated in distant and foreign tribunals by federal officials who are not accountable to tribal leaders or the community? Are basic requirements of fairness and due process met when defendants, crime victims, and witnesses are summoned to court hundreds of miles away to testify about simple but serious local crimes that occurred in their own backyards? Can a community enjoy its right to a "public trial" when a local crime is adjudicated in a non-televised trial hundreds of miles away in a city that is difficult to reach from the reservation? As these questions suggest, ${ }^{14}$ the federal Indian country criminal justice scheme is subject to a host of criticisms derived from implicit constitutional values of federalism and localism and explicit constitutional requirements of criminal procedure.

Among the chief sources of criticism of the federal Indian country criminal justice system is the prevalence of crime against Indians. ${ }^{15}$ Indians are far more likely than members of all other major racial classes to be victims of violent crime. An American Indian or Alaska Native is two-and-a-half times more likely than a member of the general public to be a victim of violent crime and twice as likely as an African American. ${ }^{16}$ From 1992 through 2001 , the average annual rate of violent victimizations among Indians was

14. This list of questions leaves out a host of equal protection questions potentially raised by prosecutions in Indian country, such as disparities between federal and state sentences for identical offenses based on the racial identities of the perpetrators and victims. The Supreme Court has generally indicated that equal protection claims premised on race are not salient in Indian law given the unique political status of Indians and Indian tribes recognized in the Constitution. See United States v. Antelope, 430 U.S. 641 (1977).

15. For an extensive review of then-existing research in involving Indians and crime, see David Lester, Crime and the Native American (1999). Lester challenges research studies asserting that Indians commit crime more than other minority groups, but does not address the assertions that Indians are victimized at higher rates. See generally also RONET BACHMAN, DEATH AND VIOLENCE ON THE Reservation (1992).

16. Perry, supra note 7 at 5-6. 
101 per 1,000 residents twelve years of age and older. ${ }^{17}$ This compares to fifty violent victimizations per 1,000 blacks, forty-one per 1,000 whites and twenty-two per 1,000 Asians. ${ }^{18}$ Sexual offenses against women and children are especially serious problems in Indian country. ${ }^{19}$

In discussing the high crime rates on Indian reservations, academics fault federal prosecutors and law enforcement agents who are accused of declining meritorious prosecutions, particularly of non-Indian offenders. Congress has found fault too, but has treated the issue as a resource allocation problem. In recent years, Congress has dramatically increased funding and positions for federal prosecutors and FBI agents who work these cases. But the problems that exist in Indian country criminal justice may be far deeper than a lack of enthusiasm by federal prosecutors or an insufficient number of federal prosecutors and investigators to perform the tasks. It may stem from structural problems in the system.

For thirty-five years, federal policymakers have moved more and more decisively in the context of Indian law and policy toward an approach that fosters "tribal self-determination" and have sought to restore the powers of tribal governments. As a result of the advance of federal Indian policy, the federal criminal justice system in Indian country no longer rests comfortably within the mainstream of federal Indian policy. To some degree it seems to be a relic, perhaps, of colonialism. While the notion of community "selfdetermination" has been enthusiastically embraced only fairly recently in federal Indian policy, it is a long-standing and hallowed norm in American criminal justice. Indeed, many of the key institutions of the federal criminal justice system, such as juries, were designed to assure community control of criminal justice. Given that American criminal justice is designed in many respects to build in "self-determination" as its own guiding principle, it is perhaps ironic that criminal justice in Indian country has been resistant to such notions.

Thus, rather than challenging the existing system on the grounds that it is inconsistent with federal Indian policy, this Article instead asks a more fundamental question: is this federal criminal justice system consistent with its own prevailing norms? In other words, this Article evaluates the federal Indian country criminal justice regime, not against norms of Indian law and policy, but against those of criminal law and policy. Specifically, this Article evaluates the federal constitutional norms that lie at the heart of American criminal justice and that are designed to ensure the legitimacy of federal criminal trials. Toward that end, Part I presents a critical description of key facets of the federal Indian country criminal justice system. Part II begins the critical evaluation by evaluating a key institutional player in the federal system, the federal prosecutor. It highlights the

17. Id.

18. Id.

19. Patricia Tuaden \& Nancy Thoennes, U.S. Dep't of Justice, Full Report on the Prevalence, Incidence, and Consequences of Violence Against Women 21-23 (2000), available at http://www.ncjrs.org/pdffiles1/nij/183781.pdf. 
handicaps faced by federal prosecutors in Indian country prosecutions and questions whether prosecutorial discretion can be exercised appropriately when "outsiders" prosecute local crimes in Indian country. Part III focuses on another key institution in criminal justice, the jury. It describes the role that juries serve in American criminal justice and explains why federal juries in Indian country cases cannot perform some of these functions, leaving them inadequate under the Sixth Amendment. Part IV turns to the somewhat related topics of venue and the right to a public trial, examining whether the existing Major Crimes Act system is consistent with prevailing First Amendment values of public access and general constitutional principles of venue and vicinage in criminal cases.

\section{The Modern Structure and Process of Indian Country CRiminal Justice}

A brief introduction to the current contours of criminal justice in Indian country, and a critical description of the process from the viewpoint of the Indian community is helpful to understanding the complex problems that the system must address.

\section{A. A Legal Description of the Indian Country Regime}

The federal Indian country criminal justice regime consists primarily of a trio of federal laws that create a complex jurisdictional framework. ${ }^{20}$ The first of the three statutes is 18 U.S.C. $\S 1151$, which defines no offenses but merely sets forth the geographic scope of federal Indian country jurisdiction. Literally defining the term "Indian country," $\$ 1151$ demarcates federal jurisdiction as extending to all lands within Indian reservations as well as so-called "dependent Indian communities" and allotments to which the Indian titles have not been extinguished. ${ }^{21}$ While interpretation of the statute is relatively straightforward, recent cases have imposed a distinct judicial gloss that has both expanded and narrowed the scope of the plain language in significant ways. For example, the Tenth Circuit has held that Indian country includes some federal trust lands that

20. The entire scheme is set out in much greater detail in Robert N. Clinton, Criminal Jurisdiction Over Indian Lands: A Journey Through a Jurisdictional Maze, 18 ARIZ. L. REv. 503 (1976). The United States Code defines a handful of other offenses related to highly specific subjects, such as intoxicating liquors, 18 U.S.C. $\$ \S 1154-56$ (2000), gambling, 18 U.S.C. $\$ 1166(2000)$, and unauthorized hunting, 18 U.S.C. $\S 1165$ (2000), but these offenses are rarely prosecuted.

21. 18 U.S.C. $\$ 1151$ (2000) provides:

Except as otherwise provided in sections 1154 and 1156 of this title, the term "Indian country", as used in this chapter, means (a) all land within the limits of any Indian reservation under the jurisdiction of the United States Government, notwithstanding the issuance of any patent, and, including rights-of-way running through the reservation, (b) all dependent Indian communities within the borders of the United States whether within the original or subsequently acquired territory thereof, and whether within or without the limits of a State, and (c) all Indian allotments, the Indian titles to which have not been extinguished, including rights-of-way running through the same. 
do not otherwise fit neatly within the three categories set forth in the statute. ${ }^{22}$ In contrast, the Supreme Court has so narrowly defined the second category, "dependent Indian communities," that the phrase would no longer seem to apply to those communities that originally gave the phrase its meaning. ${ }^{23}$

The other two key statutes are the Major Crimes Act, set forth at 18 U.S.C. $\S 1153$ and another statute known variously as the Indian Country Crimes Act or the General Crimes Act ${ }^{24}$ (the latter will be used here, in contradistinction to "Major Crimes Act"). The General Crimes Act provides that the general federal laws enacted to apply to locations within exclusive jurisdiction of the federal government, also known generally as the federal enclaves laws, apply in Indian country. One of the federal enclaves laws, the Assimilative Crimes Act, ${ }^{25}$ provides that any state criminal law of the state in which the lands are located can be assimilated if there is no federal criminal law on point. Because of this provision, the General Crimes Act allows a federal prosecution for virtually any conceivable offense, whether misdemeanor or felony.

While the General Crimes Act appears tremendously broad, it has some limitations. First, as a matter of federalism, federal courts have held that the law may not be used to prosecute a crime in which no Indians are involved. ${ }^{26}$ As a result, the General Crimes Act may be used to prosecute a non-Indian only if the non-Indian has committed a crime against an Indian. Second, the General Crimes Act explicitly excludes offenses by one Indian against another. Thus, a prosecution against an Indian under the General Crimes Act is available only if the Indian commits a crime against a non-Indian. The General Crimes Act existed before the Major Crimes

22. See Okla. Tax Comm'n v. Chickasaw Nation, 515 U.S. 450, 453 n.2 (1995) (using term “informal reservation"); United States v. Roberts, 185 F.3d 1125, 1129-31 (10th Cir. 1999) (declaring that Indian Country jurisdiction extends over tribal lands held in trust by the federal government, even though such land is not within an Indian reservation, is not an allotment, and does not technically meet the definition of "dependent Indian community").

23. Compare Alaska v. Native Vill. of Venetie Tribal Gov't, 522 U.S. 520 (1998), with United States v. Sandoval, 231 U.S. 28 (1913). See also Kristen A. Carpenter, Interpreting Indian Country in State of Alaska v. Native Village of Venetie, 35 TULSA L.J. 73 (1999) (criticizing the Venetie decision's narrow interpretation of the term).

24. Section 1152 declares:

Except as otherwise expressly provided by law, the general laws of the United States as to the punishment of offenses committed in any place within the sole and exclusive jurisdiction of the United States, except the District of Columbia, shall extend to the Indian country.

This section shall not extend to offenses committed by one Indian against the person or property of another Indian, nor to any Indian committing any offense in the Indian country who has been punished by the local law of the tribe, or to any case where, by treaty stipulations, the exclusive jurisdiction over such offenses is or may be secured to the Indian tribes respectively.

18 U.S.C. $\S 1152(2000)$.

25. 18 U.S.C. $\$ 13(2000)$.

26. See United States v. McBratney, 104 U.S. 621 (1882) (providing that if a non-Indian commits a crime against another non-Indian, then the state has exclusive jurisdiction because there is no federal interest in the case). 
Act and originally arose as a way to address conflict between Indians and settlers and to federalize protection of each against one another. ${ }^{27}$

The Major Crimes Act addressed this second limitation. As a matter of respect for the sovereignty of Indian tribes, Congress never applied the General Crimes Act to offenses between Indians. ${ }^{28}$ In the Major Crimes Act, however, Congress gave federal prosecutors authority to prosecute certain "major" crimes by Indians against Indians or others. The Major Crimes Act thus intruded into an area of exclusive tribal sovereignty and made federal law enforcement officers the primary agents for adjudicating serious crimes on Indian reservations.

Viewed together, the Indian country definition, the Major Crimes Act, and the General Crimes Act constitute the jurisdictional apparatus for bringing criminal cases in Indian country into federal court. None of these laws, however, provides the substantive offenses to which they refer. The substantive definitions must be found elsewhere in the criminal code and, if the Assimilative Crimes Act is used, in state law. This means, of course, that the serious crimes in Indian country are defined by federal and state officials, not by tribal officials.

Complementing this trio of federal statutes is the Indian Civil Rights Act. That Act strips tribes of jurisdiction over crimes punished by sentences greater than one year of imprisonment or a fine of more than $\$ 5000 .{ }^{29}$ As a result, tribes may define and prosecute any offense, but because of the sentencing limitation, tribal offenses would be labeled federally as misdemeanors. As a result, though many tribes have active criminal court dockets, only the federal government-and not tribes-can address serious crimes with felony sentences. The Indian Civil Rights Act thus has the effect of elevating the importance of the federal criminal justice regime in Indian country and giving it primacy.

27. See Clinton, supra note 20 , at 537.

28. Thus, while most of the Indian law and policy criticisms of the Major Crimes Act set forth above do not apply to prosecutions under the General Crimes Act, many of the criticisms from the standpoint of constitutional criminal procedure set forth below will apply.

29. 25 U.S.C. $\$ 1302(2000)$. 


\section{B. A Practical, Critical Description of the Process \\ of an Indian Country Case ${ }^{30}$}

The FBI has investigative jurisdiction over all the crimes listed in the Major Crimes Act. ${ }^{31}$ However, Indian country cases differ in several respects from most other crimes investigated by the FBI. First, the cases are almost always reactive. That is, a crime occurs and is then investigated by federal law enforcement. In most cases, it is a singular event and not part of an ongoing criminal enterprise. Few proactive investigations occur in Indian country. As a result, few sophisticated law enforcement tools are used at the field level in Indian country. It is exceedingly rare, for example, for Indian country FBI agents to employ wiretaps, to execute trap and trace or pen register subpoenas on phone companies, or to work with informants who have infiltrated a criminal organization. Indeed, undercover operations are especially rare, partially because of the great difficulty outsiders have infiltrating criminal organizations in Indian communities. With the exception of an occasional polygraph exam or DNA or fingerprint analysis, Indian country cases call on few of the specialized skills of the FBI.

Second, though the offenses are "major" and often tremendously important in the communities where these crimes occur, almost all of the crimes are routine, local and simple cases involving violent crimes that, in another context, would be characterized as "common street crimes" and that would not be investigated by federal officials but for the Indian country nexus. Given the FBI's many other responsibilities, such as counterintelligence, terrorism prevention, and the investigation of other serious offenses, such as organized crime and complex narcotics conspiracies, Indian country crimes rarely rank high among the FBI's priorities. As a result, the moniker "major" is somewhat misleading as an expression of FBI interest and prioritization.

The routine and unsophisticated character of these cases has ramifications at both the organizational and the individual level. At the organizational level, few FBI agents are assigned to Indian country investigations. In contrast to the team approach that prevails in many FBI

30. The authority for this section of the Article, except where otherwise noted, is the author's own admittedly subjective viewpoint derived from his experience as a federal prosecutor in an Indian country district and from conversations with other former and current Indian country federal prosecutors, such as Norman Bay (D.N.M.), Kathleen Bliss (D. Nev.), Chris Chaney (D. Utah), Jeff Davis (W.D. Mich.), Jonathon Gerson (D.N.M.), Tom Heffelfinger (D. Minn), Diane Humetewa (D. Ariz.), Joseph Lodge (D. Ariz.), Arvo Mikkanen. (W.D. Okla.), Cliff Wardlaw (D. Minn.), and Sam Winder (D.N.M.). It also reflects impressions gained from several federal public defenders, such as John Butcher (D.N.M.), Vito De La Cruz (D. Nev.), Michael Keefe (D.N.M.), John Rhodes (D. Mont.), and Jon Sands (D. Ariz.). Finally, this section also reflects my impressions gained from conversations with several FBI agents, such as Special Agent Frank Chimits. While facts were gleaned from my own experience and each of these conversations, some of the officials named above would disagree strongly with the conclusions I have drawn. I imply no endorsement.

31. See U.S. Dep't of Justic, United States attorneys' Manual: Title 9, Criminal. Resource ManUAL $\$$ 675-76, available at http://www.usdoj.gov/usao/eousa/foia_reading_room/ usam/title9/download.htm [hereinafter U.S. ATr'Ys' MANUAL] (setting forth authority for federal law enforcement in Indian country within Memorandum of Understanding between the United States Department of the Interior, Bureau of Indian Affairs and the United States Department of Justice, Federal Bureau of Investigation in November 1993). 
investigations, the agent handling Indian country investigations often works alone in rural settings and may travel hundreds of miles of reservation roads in the course of a week's work. ${ }^{32}$ Because of the high caseload that each agent bears, agents often work together only when crucial to personal safety. ${ }^{33}$ As a result, the individual FBI agent may find such work lonely, dull, or, given the subject matter, even unpleasant. ${ }^{34}$ To the extent that an agent does work with another person, it is often a tribal officer.

Most Indian country agents work out of small offices called "resident agencies" or "RAs" which are often staffed with just two or three other agents in small cities bordering or near Indian reservations. ${ }^{35}$ An agent posted at an RA may not have signed up to the FBI expecting to be posted to such an out-of-the-way location or to be handling the kind of cases that fill the caseload of the average Indian country special agent, such as sexual abuse of children. Because Indian country tends not to be a prestigious posting, the agents in the RAs are often rookies or "first office agents" who seek transfer as soon as they are eligible, leading to sometimes high turnover among the FBI personnel dealing with Indian country offenses. ${ }^{36}$

The law enforcement arm of the Bureau of Indian Affairs also possesses investigative jurisdiction over Indian country offenses. ${ }^{37}$ Because of the overlap in investigative jurisdiction with the FBI, BIA patrol officers and criminal investigators generally handle offenses of less serious magnitude than the ones handled by the FBI. One key difference between the FBI and the BIA is that the federal policy of tribal self-governance has taken hold within the BIA law enforcement program. Through agreements with the Department of the Interior known as " 638 contracts" and "self-governance

32. Over the years, the FBI has begun several initiatives with local tribal law enforcement agencies to address some of these problems. The current initiative is called the "Safe Trails Task Forces." Fed. Bureau of Investigation, Indian Country Crime (Oct. 28, 2004), http://www.fbi.gov/ hq/cid/indian/safetrails.htm.

33. This is obvious from FBI statistics. In the calendar year 2004, approximately 100 FBI agents worked on Indian country cases nationwide. Collectively, they instituted numerous investigations culminating in approximately 1900 cases. See Grant D. Ashley, Executive Assistant Dir., Fed. Bureau of Investigation, Remarks at the National Native American Law Enforcement Association's 12th Annual Training Conference (Oct. 28, 2004), http://www.fbi.gov/pressrel/speeches/ashley 102804.htm.

34. Violent crimes investigations sometimes involve blood spatter, collection of semen, and other "blood and guts type" evidence, or, even worse, difficult social and emotional issues, such as sex crimes against children.

35. For example, Indian country RAs are located in Flagstaff and Pinetop, Arizona; Bemidji, Minnesota; Gallup and Farmington, New Mexico; and Vernal and Monticello, Utah, among other cities. See, e.g., Phoenix Division Regional Offices, http://phoenix.fbi.gov/pxterrit.htm (last visited Dec. 17, 2005) (listing RAs in the Arizona area).

36. According to federal law enforcement lore, Indian country RAs once served a punitive role as places to exile FBI agents that fouled up important cases or were otherwise the subject of disfavor within the Bureau. See infra note 30.

37. See 25 U.S.C. $\$ 2803$ (2000) (BIA law enforcement authority); see also U.S. ATT'Ys' MANUAL supra note $31, \S \S 675-76$ (including a memorandum of understanding between the United States Departments of Justice and Interior reaching agreement that each United States Attorney will prepare local guidelines indicating which law enforcement agency has primary jurisdiction and that jurisdictional disputes will be resolved, if possible, at the field level). 
compacts, ${ }^{38}$ many tribal governments have undertaken the BIA's law enforcement and investigative responsibilities on their reservations. In undertaking this responsibility under federal law, a tribal government effectively substitutes its own tribal police for BIA law enforcement (just as BIA law enforcement once supplanted tribal law enforcement institutions). ${ }^{39}$ Since investigation precedes a criminal prosecution, the "devolution" to tribes of this important function can give tribal law enforcement a key role in criminal cases. As a result, in some cases involving less serious felony offenses, tribal police will work directly with federal prosecutors.

Because authority for investigation of such crimes overlaps between independent law enforcement agencies, jurisdictional disputes can develop. ${ }^{40}$ Often, uniformed BIA or tribal police arrive on the scene first. The overlap in the jurisdictional roles of the FBI and BIA, while sometimes leading to conflict, has some advantages to the community in that one agency can investigate even if another declines to do so. ${ }^{41}$

Because alcohol is involved in a substantial number of the crimes in Indian country, ${ }^{42}$ many cases are not difficult to solve. Suspects rarely employ sophisticated strategies for covering their tracks. Often the perpetrator is known and the most difficult challenge is to locate him and make an arrest. On rural parts of reservations that are accessed by dirt roads without street signs or visible addresses on the homes, however, effective investigation

38. See 25 U.S.C. § 450(1) (Supp. V 1975) and 25 C.F.R. § 271 (1996). Although neither BIA officials nor the tribes were particularly happy with practical implementation of the 638 contract program, the regime was hampered by the Byzantine bureaucracy of the BIA, which compartmentalized functions in a manner that frustrated flexibility among those providing services. See Tadd M. Johnson \& James Hamilton, Self-Governance for Indian Tribes: From Paternalism to Empowerment, 27 CONN. L. Rev. 1251, 1264-66 (1995).

39. See, e.g., 25 U.S.C. $§ 2804(f)$ (2000) (recognizing that tribal law enforcement officers possess the status of federal officers for certain purposes when working under a 638 contract for law enforcement); see also William T. Hagan, Indian Police and Judges 20-21 (1966) (describing various traditional tribal law enforcement institutions such as the Cherokee Lighthorsemen).

40. HaGAN, supra note 39 , at 20-22.

41. Investigative decisions by Tribal or BIA law enforcement officials not to investigate or not to refer a case for prosecution are not decisive because the FBI may independently investigate and make its own referral if it deems appropriate. See U.S. ATT'Ys' MANUAL, supra note 31, $\$ \S 675-76$ (including memorandum indicating that tribal or Interior law enforcement must notify the FBI of any decision to decline to investigate a criminal matter falling within the investigative authority of either agency). Likewise, investigative decisions by tribal law enforcement officials to investigate and refer a case are reviewed by a United States Attorney who can, of course, decline to prosecute. Id.

42. See Christine Zuni Cruz, Four Questions on Critical Race Praxis: Lessons from Two Young Lives in Indian Country, 73 FordHaM L. Rev. 2133, 2145, 2154 (2005) (noting "oppressive force of alcohol in the Native community"); Kathy Helms, Navajo Nation No.1 in Crime, INDEP. (Gallup, N.M.), Nov. 1, 2004, at 2 (quoting Assistant United States Attorney Diane Humetewa, "Ninety-nine percent of the cases referred to [the Arizona United States Attorney's Office] involve alcohol or substance abuse .....); see also LAWREnCE Piersol ET AL., U.S. SENTENCING COMm'N, REPORT OF THE NATIVE AMERICAN Advisory Group 35 (2003), available at http://www.ussc.gov/ NAAG/NativeAmer.pdf ("Across the board, alcohol plays a significant role in all violent crime arising in Indian country."); Stewart Wakeling et al., U.S. DeP'T OF Justice, Policing on AMERICAN INDIAN RESERVATIONS 19 (2001) (noting that alcohol-related crime is the leading crime problem in Indian country and explaining the repeated citation of alcohol abuse as a challenge facing Indian policing and Indian communities in general). 
may require significant local knowledge of homes and other locations. It may also require some knowledge of family ties and social networks in the community. Because Indian communities are often relatively closed to strangers, federal law enforcement officers such as FBI agents face a significant handicap and often find themselves at the mercy of tribal officers. Indeed, a tribal police officer that lives in a community is almost certain to have stronger contacts and may very well be able to produce information in an investigation that a federal agent would never discover. As a result, federal agents often develop close working relationships with tribal officers.

After the arrest, federal officers are likely to extract a confession. Confessions seem far more common in federal Indian country cases than in other federal cases, such as narcotics cases. While the relative lack of sophistication of the criminal defendant and the strength of the evidence may occasionally work to help the FBI agent extract a confession, at least one commentator has speculated that the tribal values of honesty and of being forthright in accepting responsibility for one's actions that disrupted the community may also play a role. ${ }^{43}$

Once the perpetrator is found (sometimes in tribal custody), federal agents must make the arrest (or take custody) and take the perpetrator before a United States Magistrate Judge for an initial appearance. Because the cases tend to be reactive, it is often at the time of the arrest, or only shortly before, that the United States Attorney's Office first learns of the offense.

The first substantive prosecutorial step in a federal major crimes case is review of the evidence and the determination of whether or not to pursue a prosecution. Following the arrest, federal prosecutors work with the arresting officer to prepare a criminal complaint or else direct that the perpetrator be released. If the United States Attorney's Office ("USAO") decides to proceed, it will file a criminal complaint. The perpetrator will then be taken to the nearest federal court for an initial appearance. During that appearance, the federal prosecutor may file a motion for a detention hearing. ${ }^{44}$ If so, the defendant is "bound over" and remains in custody pending the hearing.

If the defendant is indigent, an attorney will be appointed to represent him in later proceedings. A substantial number of Indian country defendants are indigent and are represented by the Federal Public Defender or, if that office is unavailable or has a conflict, an attorney selected by the court from a panel of attorneys on a court-approved list of criminal defense attorneys who are willing to take cases under the court's modest fee structure.

The defense attorney will face several obstacles that may make it difficult to provide effective representation. At the outset, the defense attorney

43. Zuni Cruz, supra note 42 , at 2156 ("[T]here is a socialization to accountability that operates in indigenous societies that is not necessarily compatible with the underlying principles of American criminal law ....").

44. See 18 U.S.C. $\$ 3142(f)(2)$. A handful of federal districts with substantial Indian reservation lands have part-time magistrate judges who sit in smaller cities close to Indian reservations who serve no other purpose but to preside over initial appearances so that a perpetrator may be bound over for a detention hearing. 
may need an interpreter to communicate with the defendant ${ }^{45}$ and may face significant cultural hurdles in developing a trusting relationship. With limited resources, the defense attorney may have difficulty investigating a crime that occurred a great distance from the court (and the defender's urban office). Hours of investigative work may be consumed in traveling to and from the reservation to search for and interview witnesses. The defense team may not have the resources to send an investigator on numerous trips to the reservation. In this respect, there may be striking asymmetry between the prosecutors who use agents relatively close to the reservation and defense attorneys who lack "resident agency" offices for their investigators.

Once a defendant has been charged, and following the initial appearance, a defendant commonly appears before a United States Magistrate Judge for an arraignment and, if the United States seeks to hold the defendant in custody pending trial, a detention hearing. ${ }^{46}$ At these preliminary stages, the court fills two primary roles. The court identifies the charges that the defendant faces and formally advises the defendant of his key procedural rights. The second role is risk assessment: the court must measure the likelihood that the defendant will flee or otherwise fail to appear at future proceedings, and determine whether release of the defendant "will endanger the safety of any other person or the community.",77

The magistrate judge who must make these evaluations is almost certain to be a non-Indian who lacks any particular familiarity with the Indian community where the defendant was arrested. Moreover, if the court lies at a great distance from the community where the crime occurred, it may be difficult for the defendant and his attorney to locate and present witnesses who can assist the defendant in contesting detention. Often a defendant will meet his attorney only a short time before the arraignment and detention hearing. Even outside Indian country, such hearings often occur with imperfect and incomplete information. In the Indian country context, reliable information and witnesses are likely to be even more difficult to obtain.

In the federal system, no felony prosecution, including those for major crimes in Indian country, may proceed without an indictment issued by a grand jury. ${ }^{48}$ Thus, whether or not the defendant is held in detention, the

45. Federal courts certify Navajo interpreters. Cristina M. Rodríguez, Accommodating Linguistic Difference: Toward a Comprehensive Theory of Language Rights in the United States, 36 HaRv. C.R.-C.L. L. REv. 133, 201 n.255 (2001). However, some tribal courts routinely proceed in their own native languages, other than Navajo, such as Lakota. See, e.g., Frank PommErsheIM, Braid OF FEATHERs 69-70 (1995). This suggests that some federal Indian defendants other than Navajos might also benefit from official interpreters.

46. See 18 U.S.C. $\$ 3142$ (2000); Fed. R. Crim. P. 5(a).

47. 18 U.S.C. $\$ 3142$ (c) (2000).

48. The Fifth Amendment guarantees the right to an indictment: "No person shall be held to answer for a capital, or otherwise infamous crime, unless on presentment or indictment of a Grand Jury, except in cases arising in the land or naval forces, or in the Militia, when in actual service in time of War or public danger ...." U.S. CoNST. amend. V. This guarantee is incorporated into Rule 6 of the Federal Rules of Criminal Procedure, which sets forth the method for constituting a grand jury and applicable rules, such as the rule of secrecy. FED. R. CRIM. P. 6(3)(1). However, a criminal 
United States Attorney must next present an indictment to the grand jury or risk having the case dismissed. ${ }^{49} \mathrm{~A}$ federal grand jury consists of up to twenty-three citizens selected randomly to serve for a lengthy term-often one year, though a longer time is authorized. ${ }^{50}$ Grand jurors screen and evaluate prosecutorial charging decisions by ensuring that the evidence presented by the prosecutor is sufficient to meet a legal standard of probable cause. Though the American criminal justice system uses a grand jury for this function primarily to ensure that the community has a role in the administration of criminal justice, few or none of the grand jurors in most Indian country cases actually reside in any Indian country community. ${ }^{51}$

As an empirical matter, grand juries usually issue the indictments that federal prosecutors seek. ${ }^{52}$ Once the indictment is issued, the defendant will be arraigned again on the indictment. The defendant, in consultation with his attorney and in negotiations with federal prosecutors, will decide whether to plead guilty or go to trial. If the defendant chooses to go to trial, witnesses must be found and served with subpoenas; they will be required to travel to federal court to testify and may be required to wait around a day or two to testify, depending on the pace of the trial.

For reasons that will be addressed fully below, ${ }^{53}$ the venire from which the jury is selected is unlikely to have a single member of the Indian community in which the crime occurred. At trial, neither the prosecutor, the defense attorney, the marshals, nor the court security officers, the court reporter, the judge, or law clerks are likely to live within the community where the offense occurred. In many cases, the only other tribal member in the courtroom will be the interpreter, ${ }^{54}$ if one is needed, and the witnesses. In

defendant who cooperates may waive indictment and allow the United States to proceed on the basis of an information. FED. R. CRIM. P. 7(b).

49. FED. R. CRIM. P. 48(b).

50. FED. R. CRIM. P. 6(a), (g). The federal grand jury in districts with large numbers of major crimes prosecutions typically meets for one to three days on a monthly or semiweekly basis.

51. For a discussion of Indian representation on juries, see infra Section III.B-C.

52. Lawyers and scholars tend to be skeptical of the importance of the modern grand jury's screening power. Many believe that grand jury review represents, at best, "a modest screening power, a fact recognized by the familiar courthouse saying that a grand jury would indict a ham sandwich if the prosecutor asked it to do so." Ronald Wright \& Marc Miller, The Screening/Bargaining Tradeoff, 55 Stan. L. Rev. 29, 51 n.70 (2002) (citing R. Michael Cassidy, Toward a More Independent Grand Jury: Recasting and Enforcing the Prosecutor's Duty to Disclose Exculpatory Evidence, 13 GEO. J. LEGAL ETHICS, 361, 361 (2000)).

53. See infra Section III.B-C.

54. See Christopher Chaney, Victim Rights in Indian Country-An Assistant United States Attorney Perspective, U.S. ATT'Ys' BuLL., Jan. 2003 at 36 (noting use of a Navajo/English language translator for a nineteen-year-old witness in a typical, though fictional, case). The courts largely need interpreters not for the witnesses and the defendant, but for the judge, the jury, the prosecutor, the defender, and for purposes of creating a written record. In other words, the interpreter is needed for reasons external to the community and precisely because the community's language is not adequate for purposes of the federal court. The need for a translator is thus emblematic of the colonial nature of the system; it is designed to inflict an external justice system on communities that have existed in the same locale since before English was spoken. 
that sense, the tribunal may seem alien to the defendant, and he may not feel that he is being judged in any sense by his own community.

If the defendant pleads guilty or is convicted at trial, he will proceed to sentencing before a federal judge. The federal judge generally will not be accustomed to seeing the kind of offenses at issue in the case, except in Indian country cases. Because he has little experience with similar offenses that occur outside the reservation and are thus handled routinely in state courts, the judge may well have a skewed view of the Indian community where the crime occurred.

At sentencing, the defendant will be sentenced in accordance with the federal sentencing guidelines and other federal laws, including mandatory minimum sentences for certain crimes. As a practical matter, neither Congress nor the U.S. Sentencing Commission have considered the particular effect of the sentences on Indian communities or Indian country defendants. ${ }^{55}$ As a result, the sentences may well be substantially longer than the average sentence for a similar offense in state court. ${ }^{56}$ Moreover, though the defendant's criminal record in federal or state courts will be used to calculate his criminal history for purposes of calculating the length of his sentence, federal courts usually ignore the defendant's criminal records from tribal courts. ${ }^{57}$

Once the sentence is pronounced, the federal Bureau of Prisons will assign the defendant to a particular prison. The prison is likely to be located in a different state than where the offense occurred. ${ }^{58}$ This greater relative distance is likely to make it much more difficult for the defendant's children and other family members to visit him, a problem exacerbated by the prevailing poverty among Indian families. The defendant thus may become alienated from his family and deprived of emotional support that otherwise might have helped him survive incarceration and achieve some measure of rehabilitation.

55. PIERSOL, supra note 42; see also Native Am. Advisory Group, U.S. Sentencing Comm'n, Transcript of Public Hearing at the Judicial Conference Center (Nov. 4, 2003), http:/www.ussc.gov/NAAG/NAAGhear.pdf [hereinafter Transcript].

56. See Transcript, supra note 55. The amount of the disparity depends, of course, on the state in which the offense occurred.

57. See Kevin K. Washburn, Tribal Courts and Federal Sentencing, 36 ARIZ. ST. L.J. 403, 414-17 (2004); see also Kevin Washbum, Reconsidering the Commission's Treatment of Tribal Courts, 17 Fed. Sent'g Rep. 209, 209 (2005); Jon M. Sands \& Jane McClellan, Commentary, Policy Meets Practice: Why Tribal Convictions Should not be Counted, 17 FED. SENT'G ReP. 215 (2005); Bruce D. Black, Commentary on Reconsidering the Commission's Treatment of Tribal Courts, 17 Fed. Sent'g ReP. 218 (2005); William C. Canby, Jr., Commentary, Treatment of Tribal Court Convictions, 17 Fed. Sent'g Rep. 220 (2005); Charles Kornmann, Commentary on Reconsidering the Commission's Treatment of Tribal Courts, 17 FED. SENT'G ReP. 222 (2005).

58. The problem is exacerbated by Federal Bureau of Prisons policy. For more than a decade, the only substantial sex offender treatment program within the federal prisons was in Butner, North Carolina, which is more than 1700 miles from Albuquerque, New Mexico, and more than 1800 miles from Rapid City, South Dakota. As a result, federal defendants had to make an unfortunate choice between living near family and obtaining treatment. See MAGDELINE JENSEN ET AL., Final Report of the Sexual Offenses Subcommittee to the Native American Sentencing Ad Hoc Advisory Group, United States Sentencing Commission (2003) (on file with author). 


\section{Federal Prosecutors in Indian Country}

Because the prosecutor is, in many respects, the single most important actor in a federal Indian country case, ${ }^{59}$ an examination of the role of the prosecutor is a useful place to begin a critical examination of federal Indian country prosecutions. The prosecution and imprisonment of an Indian for an on-reservation crime against another Indian is perhaps the single most aggressive use of federal power against an Indian that routinely occurs, at least in modern times, and thus may be one of the greatest existing intrusions on internal tribal affairs. I will address three different types of problems created by the use of federal prosecutors in Indian country. The first set of problems relates to the intersection between community values, prosecutorial discretion, and prosecutorial accountability. The second major problem is a practical political dynamic that I will characterize as the "cavalry effect." And, finally, the third is a tribal governance issue that stems partially from the previous problems.

\section{A. Community Values and the Foundation of Prosecutorial Discretion and Prosecutorial Accountability}

In the American criminal justice system, the prosecutor "is the representative of the public in whom is lodged a discretion" to review the evidence and determine whether or not to bring criminal charges. ${ }^{60}$ In the United States, the power of prosecutors is routinely characterized as "tremendous",61 and the prosecutor's discretion is described as "virtually unlimited.", Prosecutorial discretion begins with the decision to charge the defendant, a most important power, but it actually extends to numerous decisions made throughout a federal case, such as which charges to include, whether to seek to have the defendant held in custody pending trial, whether to offer alternative sanctions such as pretrial diversion, whether to accept a guilty plea to

59. Mandatory minimum sentences and the overwhelming prevalence of plea bargains have arguably made federal prosecutors more powerful than judges; once the prosecutor decides which offense to charge, the prosecutor has, in effect, locked in a very narrow range of discretion for the judge in deciding the sentence. See Albert W. Alschuler, Monarch, Lackey, or Judge, 64 U. CoLo. L. REv. 723 (1993). While a jury could conceivably exercise discretion over the prosecutor's charging decision by, for example, convicting on a lesser-included offense, juries are not informed about mandatory minimum sentences or about the power of nullification. Moreover, juries are absent in the overwhelming majority of cases that are resolved through plea bargains. See Stephanos Bibas, Judicial Fact-Finding and Sentence Enhancements in a World of Guilty Pleas, 110 YALE L.J. 1097, $1149-50$ (2001) (noting that only $4 \%$ of adjudicated felons have jury trials, and $5 \%$ have bench trials, while $91 \%$ plea bargain).

60. United States v. Cox, 342 F.2d 167, 192 (5th Cir. 1965) (Wisdom, J., concurring) (quoting United States v. Brokaw, 60 F. Supp. 100, 101 (S.D. Ill. 1945)).

61. Robert H. Jackson, The Federal Prosecutor, 24 J. Am. Judicature Soc'y 18, 18-19 (1940).

62. James Vorenberg, Decent Restraint of Prosecutorial Power, 94 HaRv. L. Rev. 1521, 1525 (1981); see also James Vorenberg, Narrowing the Discretion of Criminal Justice Officials, 1976 Duke L.J. 651, 678 ("The prosecutor's decision whether and what to charge is the broadest discretionary power in criminal [justice] administration.”). 
less than all of the offenses charged, and whether to seek sentencing enhancements. ${ }^{63}$

While the decision to prosecute for a specific offense is reviewable, to some degree, by the grand jury, ${ }^{64}$ decisions not to bring a case or to "undercharge" are entirely unreviewable. ${ }^{65}$ As Kenneth Culp Davis has recognized, "the affirmative power to prosecute is enormous, but the negative power to withhold prosecution may be even greater, because it is less protected against abuse. ${ }^{, 66}$

As a practical matter, it is incorrect to say that federal prosecutorial discretion is entirely unbounded. Federal prosecutors are guided both by general and specific directions set forth in the United States Attorney's Manual, ${ }^{67}$ which apply nationwide. Federal prosecutors generally also possess district-specific guidelines, written and unwritten, ${ }^{68}$ that inform decisions about which cases to prosecute. ${ }^{69}$ The local prosecutorial guidelines, which describe threshold facts that must exist to warrant consideration of the case for prosecution, are routinely shared with law enforcement agencies to assist agents in determining how to prioritize their investigations. ${ }^{70}$ Those United States Attorneys with Indian country criminal jurisdiction often spell out specific guidelines for the offenses enumerated in the Major Crimes Act. These local guidelines are generally not binding; they exist entirely as a matter of discretion and therefore need not be strictly followed by the prosecutors who rely on them. It is thus unclear how much effect the federal prosecutorial guidelines have on prosecutorial behavior.

63. See, e.g., Charles D. Breitel, Controls in Criminal Law Enforcement, 27 U. CHI. L. Rev. $427,428(1960)$.

64. See supra notes $48-51$ and accompanying text (discussing the grand jury).

65. See William T. Pizzi, Understanding Prosecutorial Discretion in the United States: The Limits of Comparative Criminal Procedure as an Instrument of Reform, 54 Оноо ST. L.J. 1325, 1337 (1993); see also Patrick Halligan, A Political Economy of Prosecutorial Discretion, 5 Aм. J. CRIM. L. 2, 6 (1977) (noting that the discretion to prosecute is limited to some degree by equal protection guarantees, but that the discretion not to prosecute is limitless).

66. Kenneth Culp Davis, Discretionary Justice: A Preliminary Inquiry 188 (1969).

67. U.S. ATT'Ys' MArJUAL, supra note 31, §§ 675-76; see also Bruce A. Green \& Fred C. Zacharias, Prosecutorial Neutrality, 2004 Wis. L. Rev. 837; Michael A. Simons, Prosecutorial Discretion and Prosecution Guidelines: A Case Study in Controlling Federalization, 75 N.Y.U. L. REv. 893, 934-36 (2000).

68. See, e.g., Richard S. Frase, The Decision to File Federal Criminal Charges: A Quantitative Study of Prosecutorial Discretion, 47 U. СнI. L. Rev. 246 (1980).

69. U.S. ATT'Ys' Manual, supra note 31, § 9-27.230(B)(1) (setting forth the Principles of Federal Prosecution).

70. For example, the United States Attorney's Prosecutive Guidelines for the District of New Mexico in force in 1997 provided that it would "accept any prosecutable cases which affect interstate commerce and which involve death or serious bodily injury. In all other cases there must be a provable interstate commerce nexus and the property damage must be over $\$ 10,000$." Memorandum from U.S. Att'y to Special Agent in Charge, Regarding Prosecutive Guidelines for Matters Within the Jurisdiction of the United States Attorney's Office, District of New Mexico 3 (Apr. 18, 1997) (on file with author). This guideline for arson is not unusual in that it leaves a large gray area; it does not necessarily indicate that the office will accept prosecution of cases involving greater than a $\$ 10,000$ loss that do not involve a dwelling or danger to human life. Id. 
Even where prosecutors purport to be following objective guidelines, they nevertheless have tremendous latitude because they must also make an independent and highly subjective judgment about the sufficiency of evidence to bring a case. In other words, even where the alleged facts clearly meet the guidelines, a prosecutor may well decide that the alleged facts cannot be proven beyond a reasonable doubt. Such decisions are notoriously difficult to second-guess, and no other institutional actor has constitutional standing to do so."

The tremendous breadth of prosecutorial discretion has been justified on a number of grounds. First, courts have regularly noted the practical difficulty in reviewing such decisions. ${ }^{72}$ Such decisions are based on all sorts of reasons, such as allocation of prosecutorial and investigative resources, law enforcement priorities, and subjective assessments of evidence and guilt. And few of these reasons are set forth in a written record that make them amenable to judicial review. Second, there are strong institutional concerns for preserving separation of powers between the judicial and executive branches of government. ${ }^{73}$ Third, prosecutors must retain broad discretion in a world in which they simply cannot enforce all of the criminal laws on the books. ${ }^{74}$ In addition to these practical justifications, broad prosecutorial discretion has been normatively justified by the premise that prosecutors take into account and indeed internalize the community's values and mores in determining which cases to prosecute. In other words, we trust prosecutors with broad power precisely because we expect them to exercise that power in a manner consistent with the needs of the community. Indeed, in the American system, in which many prosecutors announce their appearance in court by claiming that they represent "the people," the prosecutor is imbued with an almost moral authority that transcends mere governmental power. ${ }^{75}$

71. See, e.g., Newman v. United States, 382 F.2d 479, 481-82 (D.C. Cir. 1967) (stating that the prosecutor must consider "[m]yriad factors" and "no court has any jurisdiction to inquire into or review his decision").

72. See, e.g., Wayte v. United States, 470 U.S. 598, 607 (1985) ("“[B]road discretion rests largely on the recognition that the decision to prosecute [is based on a variety of factors and] is particularly ill-suited to judicial review.").

73. United States v. Armstrong, 517 U.S. 456, 464 (1996).

74. DAvIS, supra note 66 , at 192-93 (recognizing the nearly universal view that the prosecuting power intrinsically involves broad discretion because not all laws can be enforced, prosecution involves interpretation of statutes that are inherently uncertain, and the prosecutor must exercise discretion in determining whether evidence is sufficient); see also Green \& Zacharias, supra note 67 , at $899 \mathrm{n} .206$ ("[R]esource constraints prevent universal prosecution and incarceration of all ... who technically ... violate[] the law.").

75. Berger v. United States, 295 U.S. 78, 88 (1935), provides the most well-known expression of this moral authority:

The United States Attorney is the representative not of an ordinary party to a controversy, but of a sovereignty whose obligation to govern impartially is as compelling as its obligation to govern at all; and whose interest, therefore, in a criminal prosecution is not that it shall win a case, but that justice shall be done. As such, he is in a peculiar and very definite sense the servant of the law, the twofold aim of which is that guilt shall not escape or innocence suffer. He may prosecute with earnestness and vigor-indeed, he should do so. But, while he may strike hard blows, he is not at liberty to strike foul ones. It is as much his duty 
This moral and legal authority to act on behalf of the community is reinforced by the fact that most prosecutors are local officials entrusted by the community to perform this important function. ${ }^{76}$ The premise that the prosecutor acts with community values in mind is supported, in most non-federal American jurisdictions, by strong political checks on prosecutorial abuses. The chief prosecutor in most American jurisdictions is elected. Public accountability arises from the notion that "prosecutors are ... likely to satisfy the public's desires if their decisions have some implications for their careers." ${ }^{\prime 78}$ The political checks include direct control through election of prosecutors (or those who appoint them), to serve limited terms (in contrast to, for example, federal judges who have life tenure), and indirect control through appropriations and other legislative decisions. ${ }^{79}$ It also presumably includes indirect and informal checks such as media attention and popular opinion.

Even in the federal system, where prosecutors are appointed by the President and thus are insulated to a greater degree from electoral politics, ${ }^{80}$ the basic organizational scheme nevertheless reflects a preference for local control and the notion that a local prosecutor can better reflect local community values. Then-Attorney General, later Justice, Robert Jackson recognized that even federal prosecutors should be responsive to community values and sentiments when he recognized that "the moral climate of the United States is as varied as its physical climate," and thus even federal prosecutors "could hardly adopt strict standards for loose states or loose standards for strict states without doing violence to local sentiment." ${ }^{\text {}}$ In keeping with this admonition, federal prosecutors presumably endeavor to exercise their discretion in a manner consistent with community values.

As a local official, the federal prosecutor is in many ways little different from the state prosecutor; she is a member of the community, at least in some broad sense, for which she is prosecuting offenses and her authority

to refrain from improper methods calculated to produce a wrongful conviction as it is to use every legitimate means to bring about a just one.

76. See Pizzi, supra note 65 , at 1337; see also William T. Pizzi, Trials Without Truth (1999).

77. See Pizzi, supra note 65 , at 1337-38, 1342 (noting the political controls on prosecutors and even those appointed as federal prosecutors by the President); see also William J. Stuntz, The Uneasy Relationship Between Criminal Procedure and Criminal Justice, 107 YALE L.J. 1,22 (1997) ("On the government's side, prosecutors are bureaucrats; like other bureaucrats, their activity level is largely governed by their budgets. Rationing in this setting is akin to queuing, albeit in a system where the prosecutor defines one's place in line.").

78. Green \& Zacharias, supra note 67.

79. See Anthony C. Thompson, It Takes a Community to Prosecute, 77 Notre Dame L. Rev. 321,327 (2002) ("In a world of limited resources, prosecutors must act in accordance with the priorities of their funding authorities.").

80. Frase, supra note 68 , at 249 ("[T] not subject to popular political pressures, although he may be removed by the President.").

81. Jackson, supra note 61 , at 20. 
derives normatively from her representation of that community. ${ }^{82}$ In that respect, the only real difference, for most offenses, is that the federal prosecutor's "community" is simply a larger district than the state prosecutor's community and the range of prosecutable offenses is more narrow. Thus, it is easy for the federal prosecutor to exercise his authority in a manner consistent with community mores if he so chooses. In most circumstances, he presumably can intuit them almost as well as a state prosecutor can.

\section{B. The Federal Prosecutor in Indian Country}

An implicit justification for the modern federal Indian country criminal justice regime is that the United States has a responsibility to preserve public safety on Indian reservations. ${ }^{83}$ Indeed, the regime does not purport to be primarily responsible for public safety throughout the general community encompassing the entire federal judicial district or state but merely concerns those communities that lie within the jurisdictional confines of "Indian country," as that term is defined in the United States Code. In other words, the regime is designed to provide public safety and criminal justice in Indian country and the statutory scheme is geographically defined as applying only to that area. ${ }^{84}$ Given that background, the apparent responsibility of the prosecutor in an Indian country case is to represent-and protect-the Indian country community. ${ }^{85}$

\section{The Prosecutor as Representative of the Community}

For a variety of reasons, one might be highly skeptical of the ability of a federal prosecutor to represent the Indian country community. Unlike the usual circumstances, in which the prosecutor internalizes and acts in accordance with the mores and values of the community (of which she theoretically is a part), a federal prosecutor in Indian country may live hundreds of miles from the reservation and may not even speak the language used in that community. She may not be able to understand and internalize the values of the community that she theoretically protects.

82. See generally JAMEs EISENSTEIN, COUNSEl fOR THE UNITED STATES: U.S. ATtORNEYS In the Political and Legal Systems (1978); Whitney North Seymour, JR., United States AtToRney: AN Inside VieW of "Justice" in AMERiCa Under the Nixon Administration (1975).

83. See Contemporary Tribal Governments: Challenges in Law Enforcement Related to the Rulings of the United States Supreme Court: Hearing Before the S. Comm. on Indian Affairs, 107th Cong. 9-11 (2002) (statement of Thomas B. Heffelfinger, U.S. Att'y for the Dist. of Minn.), available at http://Indian.senate.gov/2002hrgs/071102hrg/heffelfinger.pdf ("Since 1885, when Congress passed the Major Crimes Act, United States Attorneys have had primary responsibility for the prosecution of serious violent crime in Indian country." (citation omitted)).

84. See supra note 21 and accompanying text.

85. Thus, the Indian country case stands in contrast to the normal situation in which "the prosecutor's client is the [general] public." See Green \& Zacharias, supra note 67, at $866 \mathrm{n} .106$. 
The federal prosecutor's lack of membership in the Indian country community is not the only obstacle she will face in intuiting community values. First, she is not present on a daily basis within the community to participate in ongoing communications about community values and mores. She will not know, firsthand, what the community is talking about or concerned about. Second, since many Indian communities are closed and suspicious of outsiders, it is unrealistic to believe that they will easily confide in a federal prosecutor about matters that are important to them.

This critique, at first blush, may not seem to be limited to Indian country cases. Admittedly, a federal judicial district is composed of numerous heterogeneous "communities," and members of many communities, especially the minority communities within the jurisdiction, might feel that the local prosecutors do not internalize their values and thus do not "represent" them. An African American community, for example, may feel that prosecutors are unfairly targeting it. While Indian country communities have a somewhat stronger claim because of the explicitly geographical jurisdictional grant, it is important to remember Felix Cohen's famous metaphor of Indians as the "miner's canary" with the treatment of Indians reflecting the health of American policy and democratic values beyond Indian policy.

The Indian country regime, in explicitly creating a scheme for prosecuting local offenses with no national nexus and applying only to Indian country, offers insight into our national psyche. ${ }^{87}$ While federal law may not consciously single out African American communities, its willingness to single out "Indian country" for special treatment in this way may be cause for broader concerns by other communities. In Indian country, the federal prosecutor is alien to the community and less able or unable to understand, internalize and protect, or even act in accordance with, the community's values. Perhaps such an official simply is not institutionally competent. This gives rise to a related problem.

\section{The Accountability Problem}

The alignment between the prosecutor and community values that serves as the normative foundation for broad prosecutorial discretion is supported, in most American jurisdictions, by prosecutorial accountability through the political process. The crimes enumerated and prosecuted under the federal Indian country regime are crimes that Roscoe Pound would have characterized as crimes against "local order." 88 Outside of Indian country, such crimes are routinely prosecuted by local (state) prosecutors elected by the local

86. Felix S. Cohen, Handbook of Federal Indian Law, at v (Rennard Strickland ed., 1982).

87. While some of my criticisms might also apply to certain federal enclaves such as military bases, application of federal rules on federal enclaves does not have the same ramifications as federal rules on Indian reservations where, presumably, an existing community has addressed such issues since time immemorial.

88. Roscoe Pound, Criminal Justice in America 151 (1930). 
community or county in which the crime occurred. ${ }^{89}$ Indeed, one of the common qualifications of standing for election as a state or local prosecutor is residency within the jurisdiction. ${ }^{90}$ Thus, in theory, the elected prosecutor is not only an elected agent of the people but almost always is also a member of the community in which the crime occurred. ${ }^{91}$

Though prosecutors are representatives of the public, prosecutors have their own personal interests in deciding which cases to prosecute. Many commentators have noted what might collectively be called "agency problems ${ }^{\prime \prime 2}$ that prevent perfect alignment of the interests of the prosecutors and the public. For reasons discussed immediately here and above, these "agency problems" are far more severe in Indian country. At the other end of the spectrum, some scholars have expressed appropriate concern about prosecutors who are too accountable to the community. ${ }^{93}$ Others have expressed the notion that the accountability question is more complex than it seems. ${ }^{94}$ Prosecutors may seek to vindicate community values that are reflected in laws or they may seek to vindicate community values that are inflamed in a particular egregious case. Most commentators would agree that prosecutors should resist the "momentary hue and cry" of the public in a "heated moment" and remain true instead to the public will in a more general sense as "expressed over time in the law and popular culture.".5 However, such debates are entirely academic for Indian tribes.

Federal Indian country prosecutors are less likely to feel any pressure to be accountable to either type of community will. The political power of Indian tribal communities over their (federal) prosecutors is strikingly different from the political power over the prosecutors who bring the same kind of cases in non-Indian communities. Because federal prosecutors are appointed, rather than elected, direct political accountability is absent in all Indian country cases, increasing the gulf between the interests of the prosecutors and the community.

89. Cf. Pizzi, supra note 65, at 1338 (noting that state prosecutors are almost always elected officials).

90. See, e.g., OKLa. Stat. AnN. tit. 19, $\$ 215.2$ (West 2000) ("The district attorney shall reside in the county from which he was elected during his term of office.").

91. See generally Richard H. McAdams, Race and Selective Prosecution: Discovering the Pitfalls of Armstrong, 73 CHI.-KENT L. REv. 605, 643-52 (1998) (asserting that prosecutors are, in general, representative of their communities).

92. See, e.g., Tracey L. Meares, Rewards for Good Behavior: Influencing Prosecutorial Discretion and Conduct with Financial Incentives, 64 FordHAM L. REv. 851, 865 (1995); Ted Schneyer, Legal Process Scholarship and the Regulation of Lawyers, 65 FoRdHAM L. REv. 33, 5354 (1996); Stephen J. Schulhofer, Plea Bargaining as Disaster, 101 YALE L.J. 1979, 1987-88 (1992).

93. DAvis, supra note 66.

94. See Green \& Zacharias, supra note 67 , at 870 n.116.

95. Id. at 870 . 
That is not to say that federal prosecutors are deaf to popular opinion on Indian reservations. ${ }^{96}$ To the extent that prosecutors are attuned to community concerns, though, Indians have the additional problem of dilution.

External motivations, such as the media attention that comes with a high profile case, are also problematic. ${ }^{97}$ Indian country cases rarely obtain much media exposure. ${ }^{98}$ From the federal prosecutor's perspective, an urban or suburban bank robbery may very well obtain greater and more sustained media attention than a multiple homicide on a rural Indian reservation.

Some federal Indian country prosecutors undertake extraordinary formal $^{99}$ and informal ${ }^{100}$ efforts to get to know their Indian communities. Such knowledge is absolutely crucial to the task. One federal prosecutor has explained, for example, the Navajo cultural norm against looking a person in the eye, which can be considered "offensive, an affront, even a challenge to

96. Indeed, Professor Frase's assertion that a federal prosecutor "is not subject to popular political pressures" because "[he] is not an elected official" is true as a formal matter, but it can be qualified. Frase, supra note 68, at 249; see also supra note 80 and accompanying text. A practical, albeit indirect, constraint on United States Attorneys is the fact that many such officials expect to seek other appointed or elected office in the future. See, e.g., Dan M. Kahan, Is Chevron Relevant to Federal Criminal Law?, 110 HARv. L. Rev. 469, 486 (1996) ("U.S. Attorneys are extraordinarily ambitious and frequently enter electoral politics after leaving office."). Though political ambition likely increases accountability, it does so only marginally with regard to Indian tribes. The reservation communities are just one of many constituent groups and may be the smallest and poorest such groups at that. Each Indian community is only one of many constituencies of a United States Attorney, and often a small, distant, and poor constituency. And Indian communities, like most poor and undereducated communities, are notorious for not voting. However, this appears to be changing. See, e.g., John P. LaVelle, Strengthening Tribal Sovereignty Through Indian Participation in American Politics: A Reply to Professor Porter, 10 KAN. J.L. \& PUB. PoL'y 533 (2001).

97. See Simons, supra note 67, at 932 ("[There is a] common ... desire of prosecutors to prosecute highly publicized cases.").

98. Neil M. Richards, The Supreme Court Justice \& "Boring" Cases, 4 GreEN BAG 2D 401, 403 (2001) (noting that Justice Brennan once referred to an Indian law case as a "chicken-shit" case).

99. Most United States Attorney's Offices in states with Indian country jurisdiction have explicitly designated an Assistant United States Attorney as a liaison to the Indian tribes within the jurisdiction. See U.S. Dep't of Justice, OJP Resources for Indian Country, http://www.ojp.usdoj.gov/ americannative/attysoffices.htm (last visited Dec. 17, 2005). The tribal liaison positions are somewhat political in nature, that is, the liaison is assigned a relationship with the tribal government, rather than the tribal community at large. Moreover, in some districts, the USAOs designate a civil attorney rather than a prosecutor as the liaison to avoid any awkwardness for a liaison serving a role as prosecutor and also fielding tribal complaints about prosecutions involving tribal members. Federal prosecutors are authorized, though not required, by federal law to report the declination of an Indian country prosecution to the appropriate Indian tribe. 25 U.S.C. $\$ 2809$ (b) (2000).

100. Following an outbreak of violence on the Red Lake Chippewa Indian reservation in Minnesota, the United States Attorney in Minnesota publicly said that he was redoubling federal efforts to address violent crime on that reservation. See Margaret Zack, State-Federal Project Fights Reservation Violent Crime, STAR TRIB. (Minneapolis), Aug. 30, 2002, at 2B (noting that the Red Lake Reservation, with a population of 5000 , had five homicides during a nine-month period beginning in late 2001). Among other efforts to reach out to the community, the United States Attorney attended the final game of a 2003 state high school basketball tournament to cheer for a high school team from the Red Lake Chippewa Indian Reservation. Conversation with Tom Heffelfinger, June 2003, notes on file with author. Such actions are commendable; they are not necessarily the norm. The Red Lake school shooting case in March 2005, which cost ten lives and resulted in a federal juvenile prosecution, dealt a serious blow to federal efforts to improve crime statistics on that reservation. 
the other person."101 Knowledge of and respect for such a cultural norm might make a difference in whether the prosecutor will gain or lose the assistance of a key witness. A misstep here can make the difference between a righteous conviction and a colossal waste of federal resources.

But even for federal prosecutors who are sensitive to cultural differences and concerned enough to make extraordinary efforts, ${ }^{102}$ the sheer distance between United States Attorney's Offices and many of the federal Indian reservations they serve present tremendous obstacles that the average violent crime prosecutor in the state system does not face. Perhaps as a result, United States Attorneys have been widely criticized for decades for failing to give proper attention to Indian country cases. ${ }^{103}$ The substance of such complaints almost always involves the failure to prosecute aggressively enough and almost never involves complaints of "over-prosecution." 104

Because of the non-reviewability of decisions to decline prosecution or to under-prosecute, the weak or nonexistent political accountability of federal prosecutors to tribal communities, and the lack of media interest in Indian country prosecutions, federal prosecutors feel little external pressure to treat Indian country cases seriously. Under such a scheme, well-intentioned federal prosecutors will work hard in Indian country, and many do. But even high levels of commitment and interest by federal prosecutors are no substitute for actual accountability. Those prosecutors who are not committed to Indian country cases will simply not pursue them. And in Indian country, it is often

101. Chaney, supra note 54 , at 39 .

102. Some federal prosecutors are members of Indian tribes and at least one serves his own reservation, but such circumstances are unusual.

103. See Carole Goldberg-Ambrose with Timothy Carr Seward, Planting Tall Feathers: Tribal Survival and Public Law 280, at 162 (1997) ("In practical application, federal law enforcement agents, particularly the Federal Bureau of Investigation and the U.S. Attorney's Office, have demonstrated a history of declining to investigate or prosecute violations of the Major Crimes Act."); Larry Cunningham, Note, Deputization of Indian Prosecutors: Protecting Indian Interests in Federal Court, 88 GEo. L.J. 2187, 2188 (2000) ("[M]any U.S. Attorneys have abdicated their responsibility to prosecute crimes in Indian country committed by non-Indians."); EchoHawk, supra note 12, at 99-100 ("U.S. Attorneys often decline to prosecute Major Crimes Act cases on the reservation because of a mixture of factual, legal, practical, or logistical problems."); B.J. Jones, Welcoming Tribal Courts into the Judicial Fraternity: Emerging Issues in Tribal-State and TribalFederal Court Relations, 24 WM. Mitchell L. REv. 457, 513 (1998) ("Federal prosecutors, busy with prosecuting a variety of more serious crimes, perhaps have been remiss in devoting the necessary attention to the problems that arise when non-Indians commit offenses in Indian country ...."); Peter Nicolas, American-Style Justice in No Man's Land, 36 GA. L. Rev. 895, 963 (2002) ("U.S. Attorneys, unlike state prosecutors, typically decline to prosecute in a far greater percentage of cases.... [resulting] in the underenforcement of criminal laws in Indian country."); Amy Radon, Note, Tribal Jurisdiction and Domestic Violence: The Need for Non-Indian Accountability on the Reservation, 37 U. Mich. J.L. ReFoRM 1275, 1278 (2004) ("Because federal prosecutors decline to prosecute [domestic violence], the law provides no deterrent effect ...."); Tim Vollmann, Criminal Jurisdiction in Indian Country: Tribal Sovereignty and Defendants' Rights in Conflict, 22 U. KAN. L. Rev. 387, 403 (1974) ("[O]verburdened U.S. Attorneys are not notorious for seeking further responsibilities of prosecution in Indian Country ...."); cf. Laurence Davis, Criminal Jurisdiction over Indian Country in Arizona, 1 ARIz. L. REv. 62, 72-73 (1959) (noting reluctance of federal prosecutors and federal courts to handle petty offenses over which they also have jurisdiction in Indian country, with the result that "petty frauds and simple assaults" by non-Indians against Indians, "which are fairly numerous-usually escape prosecution entirely").

104. Davis, supra note 103 , at $72-73$. 
the decisions not to prosecute, called "declinations," that cause the most grief and consternation. ${ }^{105}$ As a result, it would appear that federal Indian country prosecutors are failing in precisely the area in which their discretion is subject to the least scrutiny and accountability. ${ }^{106}$ The extensive critical commentary in academic literature may be the most serious negative repercussion that these federal officials face. ${ }^{107}$ The result is that criminal justice in Indian country is occasionally pursued aggressively and is sometime ignored, making criminal justice a haphazard event at best for Indian tribes. ${ }^{108}$

Accountability and control of governing institutions has become a key indicator of tribal success in improving tribal economic and social conditions. ${ }^{109}$ Indeed, lack of accountability by federal law enforcement has been identified as a chief problem for effective policing in Indian country. ${ }^{110}$ Given the close relationship between police and prosecutors, it follows that lack of accountability by prosecutors may pose similar problems.

In summary, the fundamental criminal law justifications for broad prosecutorial discretion simply do not apply when a federal prosecutor is working in Indian country. Unlike a narcotics distribution offense, which is subject to federal jurisdiction wherever it occurs within the exterior boundaries of the United States, the federal prosecutor has jurisdiction over Indian country offenses only if the offense occurred in Indian country. Yet the federal prosecutor is unaccountable to the relevant community and has no particular motivation to address community concerns. The Indian country regime thus imposes an important responsibility on federal prosecutors without imposing any accountability. The ramifications of this structural problem are enormous and undermine the legitimacy of the federal prosecutor's power in Indian country cases. These problems, though serious, are exacerbated by an even deeper problem in Indian country cases to which this Article now turns.

105. See id.

106. To be fair, such complaints are not limited to Indian country. As Roscoe Pound once wrote about the American system, "[c]omplaint of non-enforcement is as old as the law itself." Pound, supra note 88 , at 12 .

107. See supra note 103 and accompanying text (criticizing federal prosecutors for high declination rates).

108. My colleague Michael Tonry offered the important insight that under-prosecution by federal prosecutors may not necessarily be problematic because it presumably makes tribal justice systems more relevant in cases in which the federal authorities decline to prosecute.

109. See generally Stephen Cornell \& Joseph P. Kalt, Where's the Glue? Institutional and Cultural Foundations of American Indian Economic Development, 29 J. Socio-EcoN. 443 (2000); Stephen Cornell \& Joseph P. Kalt, Sovereignty and Nation-Building: The Development Challenge in Indian Country Today, 22 Am. Indian Culture \& Res. J. 187 (1998); Stephen Cornell \& Joseph P. Kalt, Where Does Economic Development Really Come from? Constitutional Rule Among the Contemporary Sioux and Apache, 33 ECON. INQUIRY 402 (1995).

110. WAKELING ET AL., supra note 42 at $43-44,49$ (concluding that accountability for policing on Indian reservations is diffused both by federal control that reduces tribal involvement and by diffusing authority among numerous different bureaucratic actors). 


\section{Federal Prosecutors and the Cavalry Effect}

For many Americans, the phrase, "the cavalry has arrived," has come to be a humorous and informal euphemism for the arrival of help or rescue; in popular usage, the phrase presumably creates a sense of relief in the listener. For Indian tribes, in contrast, the arrival of the cavalry has rarely been cause for relief or celebration and it often has quite the opposite connotation in Indian country. To members of many Indian tribes, the word "cavalry" brings to mind oppression, rapaciousness, ${ }^{111}$ murder, and even genocide. ${ }^{112}$

In Indian country, the federal government is held in the esteem it has earned in more than two centuries of federal-tribal relations. ${ }^{113}$ Its reputation in Indian country has been forged, in part, by the nineteenth-century cavalry officers who committed atrocious actions, such as murder, ${ }^{114}$ and the Indian agents who committed atrocious omissions, such as the withholding of treaty-guaranteed food and supplies in winter. ${ }^{115}$ Its reputation was formed by the actions of government officials who used gifts of smallpox-infected blankets to destroy tribal communities ${ }^{116}$ and by federal officials who unilaterally violated treaties and encouraged private actors to do the same, ${ }^{117}$ and, in more recent years, the federal trustee that lost track of the records of millions and perhaps billions of dollars of Indian assets held by the Department of the Interior in tribal accounts and Individual Indian Money accounts. ${ }^{118}$

Enter the well-intentioned federal prosecutor seeking to prosecute a violent crime in Indian country. While federal prosecutors may be talented and committed public servants who are trying to "do good" by helping to provide public safety or bringing justice to Indian country, each carries tremendous moral, emotional, and symbolic freight of which he may not

111. See Edward lazarus, Black Hills White Justice (1999) (discussing General George Custer's extraordinary efforts to appeal to gold prospectors to violate federal treaty obligations that protected the Black Hills in the Great Sioux Nation).

112. While words like "genocide" should be used advisedly, it is surely appropriate in the context of the Wounded Knee and Sand Creek massacres, both of which involved the indiscriminate killing of women and children by American soldiers. See ANGIE Debo, A History OF THE INDIANS of THE United States, 194-95 (Sand Creek), 292-93 (Wounded Knee) (1989).

113. Then-Assistant Secretary Kevin Gover issued an apology to tribes on behalf of the BIA in September of 2000. Brian Stockes, Gover Apologizes for Atrocities of the Past, INDIAN CounTry TODAY, Sept. 20, 2000, available at http://www.indiancountry.com/content.cfm?id=631.

114. DEBo, supra note 112, at 194-95, 292-93.

115. See Minnesota v. Mille Lacs Band of Chippewa Indians, 526 U.S. 172 (1999).

116. For one account and citation to much of the historical literature on these events, see Gloria Valencia-Weber, The Supreme Court's Indian Law Decisions: Deviations from Constitutional Principles and the Crafting of Judicial Smallpox Blankets, 5 U. PA. J. Const. L. 405, 405-07 (2003).

117. See LaZarus, supra note 111.

118. See Cobell v. Norton, No. 1:96CV01285, 2003 U.S. Dist. LEXIS 14303 (D.C. Cir. Aug. $20,2003)$. 
even be aware. Indians and Indian tribes have long memories. Such is the power of oral traditions. ${ }^{119}$

Though experiences vary from tribe to tribe, the federal prosecutor in Indian country is, in some respects, the direct lineal descendant of the bluecoated, sword-wielding cavalry officer; the prosecutor represents the very same federal government that committed cruel and violent acts against Indian tribes for more than a century. He represents the government that has made and then broken sacred promises. Yet he shows up on the tribal member's doorstep with the claim, "I am here to help you obtain justice." Given the history of federal-tribal relations, tribes have every reason to be suspicious of such an official and such a claim. In a real sense, for many reservation Indians, the federal government continues to represent the enemy.

In such a context, the federal prosecution creates a political dynamic in the tribe that must be addressed in virtually every case. Consider a typical case of sexual abuse of a child: after the child victim reluctantly reports an incident of abuse by another family member, it is surprisingly common for the victim's family members to align themselves with the defendant and against the victim. This is not unheard of outside Indian country, ${ }^{120}$ but it represents a particularly serious problem in Indian country cases. ${ }^{121}$ The dynamic, though extremely unfortunate, is explainable. When the federal government accuses a community member of a heinous offense and brings a criminal complaint or an indictment, the community may naturally become protective of the accused defendant in the face of this outside authority, even if the charges are based on a report by another tribal member. The family may not perceive its choice as one between the perpetrator and the victim, but between a tribal member and the United States government. As a result, when the family chooses sides, it may line up behind the perpetrator and against the child who has been victimized.

Given the long history of federal-tribal relations, the federal prosecutor simply may not be anyone whom the community has any reason to trust. ${ }^{122}$

119. See, e.g., John W. Ragsdale, Jr., Some Philosophical, Political and Legal Implications of American Archeological and Anthropological Theory, 70 UMKC L. REv. 1, 45-46 (2001) (describing the power and legitimacy of tribal oral histories).

120. Christine Adams, Note, Mothers Who Fail to Protect Their Children from Sexual Abuse: Addressing the Problem of Denial, 12 YAle L. \& Pol'y Rev. 519, 523-24 (1994) (describing the phenomenon and some of its harms).

121. EchoHawk, supra note 12, at 99 (noting that an Indian parent's fear of losing custody can cause the parent to support "herself, her family, and even the perpetrator" against white institutions (quoting Irl Carter \& Lawrence J. Parker, Intrafamilial Sexual Abuse in American Indian Familes, in Family Sexual Abuse: Frontline Research and Evaluation 106, 114 (Michael Quinn Patton ed., 1991))).

122. Id. ("Many Indians distrust the legal and social authorities that could be most helpful to them because of past experiences of unjust treatment."); $c f$. Ronald S. Fischler, Child Abuse and Neglect in American Indian Communities, 9 Child Abuse \& Neglect 95, 98 (1985) (noting that even Indian Health Service physicians are "mistrusted as outsiders and federal government employees"). This phenomenon is familiar to many criminal law professors who teach State v. Williams, 484 P.2d 1167 (Wash. Ct. App. 1971), a tragic case in which uneducated American Indian parents were charged with manslaughter after failing to obtain medical treatment for their seventeen-monthold son for fear that the baby would be taken from them. 
The result is that the child victim is victimized anew by a political dynamic that aligns the victim with the United States and against the community and the defendant. ${ }^{123}$ This dynamic may well cause further psychological injuries to the child victim of sexual assault and lead to the victim's alienation and estrangement from family members. In that respect, a new harm is done to the child that might not have occurred in the absence of the federal prosecutor. According to experts in the field, this alienation of a child from the family often has psychological ramifications that are even more serious than the harm done by the perpetrator of the sex offense. ${ }^{24}$ In addition to harming victims, the dynamic may cause numerous lesser evils, such as practical problems in prosecutions. It sometimes, no doubt, causes victims to recant and frustrates effective prosecutions of sexual predators. ${ }^{125}$ As a result, sexual predators are not effectively removed from the community.

Use of a federal prosecutor likely creates a host of other less-serious problems as well. Even leaving out the emotional and historical baggage that creates the political dynamic that I will characterize as the "cavalry effect," child sex abuse cases are among the most difficult cases to prosecute successfully, even in the best of circumstances. As an alien to the community, the federal prosecutor is likely to find it difficult to communicate with the Indian child and even more difficult to convince the child victim to participate in a trial. As evidence that these problems are very real, federal prosecutors have taken to employing "victim-witness coordinators"126 who often work to bridge the cultural gap between the Indian victims and the federal prosecutors. ${ }^{127}$ Without the assistance of the victim-witness advocates, Indian country prosecutions would be far less successful.

While the child sexual assault case presents perhaps the most tragic instance of this phenomenon, the "cavalry effect" likely occurs, to some degree, in any case in which the United States sides with an Indian victim against an Indian perpetrator in an intratribal dispute. Indeed, the dynamic has existed in tribes since the early nineteenth century in many different circumstances as tribal members turned against others who assisted federal officials. ${ }^{128}$

The cavalry metaphor offers one other key insight: the cavalry chooses its battles carefully and then leaves when the battle is over. One telltale sign of the lack of trust of federal law enforcement and prosecutors is the fact

123. This phenomenon is present in many intrafamily child sex abuse cases, see Adams, supra note 120 , but it is likely exacerbated in cases involving a federal prosecutor and an Indian community.

124. Id. (citing numerous authorities).

125. See generally Fischler, supra note 122, at 102 (noting that families often suppress evidence and bring pressure on victims to change their testimony).

126. See, e.g., Office of the U.S. Attorney, Eastern District of Wisconsin, Victim and Witness Assistance Unit, http://www.justice.gov/usao/wie/vicwit/ (last visited Dec. 17, 2005).

127. The USAOs frequently hire tribal members to serve in these positions.

128. Cf. Ex parte Crow Dog, 109 U.S. 556 (1883); Morris L. Wardell, A Political HisTORY OF THE ChEROKEE NATION 1838-1907, at 16-19 (1938) (discussing the murder of Cherokee leader John Ross apparently for his role in agreeing to federal efforts at Cherokee removal). 
that many crimes are never even reported. ${ }^{129}$ One key reason for the failure to report is that victims do not trust the federal authorities to protect them from retaliation..$^{130}$ Like the cavalry, federal prosecutors and FBI agents swoop in occasionally to prosecute a perpetrator, but they do not maintain a constant presence and do not necessarily consider the broader impact of their work. They address only the serious offenses and they leave when each case is concluded. It is up to the tribal community to address other offenses and the aftermath of the felony and to attempt to restore the fabric of the community. Even assuming that the federal prosecutors who agree to handle such cases are generous, selfless, and committed to bettering the lives of the reservation community (as most of them no doubt are), even the best of intentions may not always be able to overcome the handicaps noted herein.

Consider one obvious alternative approach: a tribal prosecutor. As a member of the Indian country community, a tribal prosecutor might face few of the handicaps that the federal prosecutor faces. A tribal prosecutor would not be forced into the same dynamic-she could represent the community and the community would feel less of a need to attempt to protect the defendant against an external authority. In addition, unlike the federal prosecutor, a tribal prosecutor would presumably live within the community. This would convey a much stronger sense of interest and investment in the community and would allow the prosecutor to help the community address the collateral issues that arise from the prosecution. The presence of the prosecutor within the community might also give greater comfort to those victims of crime who are unwilling to come forward. Moreover, a tribal prosecutor might act-in a variety of ways-in a fashion more compatible with community norms.

\section{Obstacles to Tribal Governance and Self-Determination}

In addition to the problems noted above, the role of federal prosecutors creates a serious obstacle to tribal self-determination. Use of a federal prosecutor to address major crimes between Indians sends a clear message of inferiority about tribal law enforcement and tribal courts, that is, that tribes cannot handle felonies. And it robs the tribal community of leadership in one of the most important areas of governance: maintenance of public safety and criminal justice. In some respects, the system can create a vacuum of tribal leadership on public safety issues that can exacerbate crime problems by sidelining the people who might be best able to address these serious issues.

Consider the political ramifications at the tribal level. In myriad ways, federal prosecutors need the assistance of tribal governments in prosecuting Indian country cases. They may need evidence from a tribal registrar that a

129. WAKELING ET AL., supra note 42, at 13-14.

130. Id. 
particular victim or defendant is a tribal member. ${ }^{131}$ Or they may need official tribal real property records documenting the status of the land on which the offense occurred. Or they may simply need help locating witnesses. But even in circumstances in which the assistance of tribal officials is crucial to the prosecution of the case, it may be politically problematic for a tribal official to appear to be assisting federal prosecutors in the prosecution of a tribal member. ${ }^{132}$ In such a case, the system essentially asks a tribal official to take sides not only against one of his own constituents but with a longtime enemy. In that respect, the "cavalry effect" may animate tribal officials in the same way that it takes hold in Indian families; it may make tribal officials reluctant to assist federal prosecutors.

The existence of the federal prosecutor thus creates structural barriers to tribal participation in the prosecution. While tribal leaders may be criticized when they fail to provide assistance in such circumstances (and perhaps they should be), these structural problems simply do not exist in other federal prosecutorial contexts or in state prosecutions of crimes equivalent to those enumerated in the Major Crimes Act. This handicap is created solely by the dynamics of the federal scheme.

Other serious political ramifications exist as well. Tribal officials are likely more knowledgeable than federal officials about remote Indian reservations and are also likely to be much more responsive to the tribal community. Yet a tribal leader running for election would be ill-advised to promise his constituents that he could address serious public safety and criminal justice problems on the reservation; he simply lacks control of the key resources. ${ }^{133}$ To make such a promise, he would need to have assurances from federal officials. Given the history of promises by federal officials, even in sacred treaties, a tribal official would be foolish to count on any such assurance. As a result, even in circumstances in which tribal governments do not actively seek to frustrate federal prosecutions, tribal leaders are much less likely to be invested in felony criminal justice. One of the telltale signs of the lack of official interest in these issues is the fact that crime statistics are so difficult to obtain for Indian reservations. ${ }^{134}$ One would be hard-pressed to find a mayor of a major American city who was unaware of the crime rate for that city. Yet tribal leaders do not routinely collect such data and would be hard-pressed to answer such a question, partially no doubt because they often do not have line authority over the law enforcement officers involved. ${ }^{135}$ If tribal political

131. United States v. Prentiss, 273 F.3d 1277 (10th Cir. 2001) (suggesting that proof of tribal status of victim and or defendant may be an element of the offense).

132. See, e.g., United States v. Velarde, 40 F. Supp. 2d 1314 (D.N.M. 1999). In Velarde, the Jicarilla Apache Tribe sought to quash federal subpoenas that the United States Attorney served on various tribal officials in order to establish jurisdiction over a defendant accused of raping an eightyear-old child. $I d$. The court rejected the tribe's efforts to prevent federal prosecutors from gaining access to tribal records. Id. at 1315 .

133. See supra text accompanying notes $20-57$.

134. See WAKELING ET AL., supra note 42, at vii (explaining that, for a variety of reasons, tribal-level data about crime in Indian country is unavailable).

135. Id. 
leaders are unwilling to use their limited resources or stake their reputations on improvement in this key area of tribal public policy, then improvements may never occur.

Viewed from the standpoint of federal officials, the situation is equally untenable. The existence of exclusively federal jurisdiction for felonies in Indian country shifts the apparent responsibility to maintain institutions that help to provide safe reservation environments away from local tribal officials and toward federal officials. ${ }^{136}$ The tribal leaders who have been rendered impotent by the scheme theoretically can criticize and blame the federal prosecutors but must shoulder little of the blame or accountability for the problem. Thus, while federal prosecutors lack any sense of accountability, they also likely do not even feel much appreciation for their work in many cases.

In short, the federal Indian country regime creates an unfortunate and indefensible paradox. It wrests control of the key and inherently local issue of felony criminal justice away from tribal leadership and places control over these issues in the hands of federal officials who have little accountability to the tribal community and little incentive to be responsive. The result is not only irrational from a criminal justice standpoint; it is contrary to the stated federal policies of tribal self-determination and selfgovernance.

\section{Concluding Thoughts about Federal Prosecutors ${ }^{137}$}

Locating the power to prosecute in a federal official from outside the reservation poses numerous practical problems, such as difficulty in obtaining the cooperation of witnesses at trial, and creates structural problems by often converting the tribal government into an opponent of the prosecution, even when the prosecution would otherwise have worked to produce a safer reservation environment. The cavalry effect and other problems related to the Indian country criminal justice system inflict serious costs on the community and serious damage to individual Indian defendants and victims. This model of criminal justice, in which prosecutions are handled by an outside authority and not the tribal government, creates a system that smacks more of colonialism than of rational criminal justice policy. It simply is not consistent with modern principles of federal Indian policy and it is dysfunctional from the standpoint of federal criminal justice policy. It is for this reason that federal Indian country prosecutions should be "de-colonized."

136. Cf. Simons, supra note 67 , at 931 ("When Congress expands the Department [of Justice's] authority to fight local crime, it also expands the Department's responsibility to fight local crime." (emphasis added)).

137. Because of the practical problems noted above and others, critical questions can also be raised about the ability of federal defenders to provide competent representation in Indian country cases. In the interest of space, the author leaves that subject for another day. 


\section{JURIES AND JURY COMPOSITION IN INDIAN COUNTRY}

While the prosecutor is ideally supposed to "represent" the community, the greatest opportunity for the community to participate affirmatively in the administration of criminal justice is, of course, through juries. In the American criminal justice system, the jury trial is constituted not only as a key procedural safeguard to the defendant, but to give the community a central role in the administration of criminal justice. ${ }^{138}$

The importance of the jury has been dramatically underscored-and strongly reaffirmed-in a series of recent Supreme Court cases. In Jones $v$. United States, ${ }^{139}$ Apprendi v. New Jersey, ${ }^{140}$ Ring v. Arizona,${ }^{141}$ Blakely v. Washington, ${ }^{142}$ and United States v. Booker ${ }^{143}$ the Supreme Court used the Sixth Amendment to strike down state and federal laws that sought to limit the role of the jury in American criminal justice. Juries were given a hallowed role in the American judicial system when the founders created the Constitution and the Bill of Rights. And, as these cases illustrate, that role is just as important to the criminal trial today as it was then. For reasons set forth more fully below, the Indian country community tends to be absent from the juries that hear Indian country cases. Because of the central importance of community participation, through juries, in insuring the legitimacy of federal convictions, I argue that the absence of the Indian community is a serious problem. This Part will explain why juries are important, how the Supreme Court and Congress have sought to ensure their representativeness, why Indian country juries fall short, and why challenges to this system have been unsuccessful.

\section{A. The Centrality of the Jury in American Criminal Justice}

The Constitution guarantees that "trial of all crimes ... shall be by Jury; and such Trial shall be held in the State where the said Crimes shall have been committed."144 The Sixth Amendment creates additional rules, guaranteeing, inter alia, "the right to a speedy and public trial, by an impartial jury of the State" and that the trial occur in the "district wherein the crime shall

138. Some scholars, such as Akhil Amar, argue that community involvement is not merely a safeguard for the defendant, but also represents the community's independent right to be involved in criminal justice. Akhil Reed Amar, The Bill of Rights: Creation and Reconstruction (1998).

139. 526 U.S. 227 (1999) (holding that facts rendering defendant subject to greater statutory penalties must be treated as elements of the offense and found by the jury).

140. 530 U.S. 466 (2000) (finding that facts increasing penalty beyond statutory maximum must be found by the jury).

141. 536 U.S. 584 (2002) (noting that the presence or absence of aggravating factors that would lead to imposition of the death penalty must be found by jury).

142. 542 U.S. 296 (2004) (determining that facts relevant to mandatory guidelines must be found by the jury).

143. $125 \mathrm{~S}$. Ct. 738 (2005) (recognizing that the Federal Sentencing Reform Act did not meet the Sixth Amendment requirements for jury involvement in sentencing).

144. U.S. CONST. art. III, $\$ 2$. This is often referred to as the "venue requirement." 
have been committed, which district shall have been previously ascertained by law ...." 145

While the language of the Sixth Amendment is phrased as a guarantee of the rights of the criminal defendant, both the Sixth Amendment and Article III's trial provision are thought to serve a valuable community interest as well: insuring the community's participation in the criminal justice system. ${ }^{146}$

The motivation for enacting these provisions can be found in key events that occurred shortly before this nation's founding. ${ }^{147}$ Following the Boston Massacre in which British soldiers were accused of killing American colonists, the British soldiers were tried in Boston before local juries. ${ }^{148}$ Because the British Parliament wished to prevent future trials of British soldiers, which might occur before biased juries, the British Parliament enacted the Administration of Justice Act that provided that British officials would thereafter be taken to England and tried there for crimes in the colonies. ${ }^{149}$ This Act was one of the "Intolerable Acts" complained of in the Declaration of Independence. ${ }^{150}$ Thus, at the time of the founding of the Republic, the Founders had clear reason to be aware of the need to preserve local participation in criminal justice, through the jury system. ${ }^{151}$

The Founders' concerns for preserving local control over criminal justice continue to inform interpretation of the constitutional provisions that they drafted. Writing for the Court in Smith v. Texas ${ }^{152}$ in 1940, Justice Black described juries as "instruments of public justice" and held that a jury must be constituted in large measure in a manner that ensures that it is "a body

\section{U.S. Const. amend. VI.}

146. See Toni M. Massaro, Peremptories or Peers?-Rethinking Sixth Amendment Doctrine, Images, and Procedures, 64 N.C. L. REv. 501, 546 (1986) ("One function of the jury, although not the only function, is to satisfy a community-centered interest in participation in the justice system by injecting representative community voices and values into the decision process."); see also Nancy J. King \& Rosevelt L. Noble, Felony Jury Sentencing in Practice: A Three-State Study, 57 VAND. L. REv. 885, 888 (2004) ("Theoretically, jury sentences would take into account the full range of penalties authorized by the legislature and mirror community norms concerning retribution, deterrence, incapacitation, and rehabilitation."). King and Noble also refer to juries as a "community-based barometer" of punishment. Id.

147. See generally AMAR, supra note 138, at 106; see also BERNHARD KNOLlenberG, Growth of the American Revolution 1766-1775, at 66-69 (1975) (discussing colonial upheaval over British attempts to remove treason trials to Great Britain in 1769).

148. See generally HiLler B. Zobel, The Boston Massacre 225-303 (1970) (providing a detailed account of the Boston Massacre trials, jury selections, and effects of the verdicts on the Boston population).

149. KNOLLENBERG, supra note 147, at 119 (discussing outrage over the Administration of Justice Act labeled "The Murdering Act" by many colonials); Steven A. Engel, The Public's Vicinage Right: A Constitutional Argument, 75 N.Y.U. L. REv. 1658, 1683 (2000).

150. The Declaration of IndePendence para. 17 (U.S. 1776).

151. See generally Engel, supra note 149, at 1684-85 (discussing how the Continental Congress responded to British attempts to remove trials from the hands of local juries: "The Continental Congress understood the vicinage presumption to be a structural property of the 'great right,' one that served not only the interests of the defendant, but those of the community as well").

152. 311 U.S. 128, $130(1940)$. 
truly representative of the community." ${ }^{153}$ Shortly thereafter, in Glasser $v$. United States, ${ }^{154}$ the Court indicated that a representative jury is fundamental to the "basic concepts of a democratic society and a representative government." $" 155$

The notion that the jury's primary purpose is to represent the community comes through in many modern cases as well. In Taylor v. Louisiana, ${ }^{156}$ for example, the Supreme Court held that the constitutional notion of trial by jury implicitly "presupposes a jury drawn from a pool broadly representative of the community." ${ }^{157}$ Highlighting the "political function" of the jury, the Supreme Court explained, "the jury is designed not only to understand the case, but also to reflect the community's sense of justice in deciding it."158 According to the Court, "[c]ommunity participation in the administration of the criminal law... is. . . critical to public confidence in the fairness of the criminal justice system.", 159

It would take many pages to provide a full catalogue of the Supreme Court's statements as to the role that juries serve in the American criminal justice system. The most consistent theme underlying all of these functions, however, is that the jury provides a role for the community in criminal justice. ${ }^{160}$ A recent case reflects the essence of much of the Supreme Court's rhetoric:

The opportunity for ordinary citizens to participate in the administration of justice has long been recognized as one of the principle justifications for retaining the jury system...

Jury service preserves the democratic element of the law, as it guards the right of parties and ensures continued acceptance of the laws by all the people. It affords ordinary citizens a valuable opportunity to participate in a process of government, an experience fostering, one hopes, a respect for law. Indeed, with the exception of voting, for most citizens, the honor and

153. Smith, 311 U.S. at 130. Professor Massaro argues that this represents the first time the Court recognized the interest of community values in this context. See Massaro, supra note 146, at 532. Professor Randall Kennedy finds such an interest recognized as early as Strauder v. West Virginia, 100 U.S. 303 (1880). Randall KenNedy, RaCE, Crime, and the LaW 170 (1997).

154. 315 U.S. 60 (1942).

155. Glasser, 315 U.S. at 85.

156. 419 U.S. 522 (1975).

157. Taylor, 419 U.S. at 530-31 (quoting Thiel v. S. Pac. Co., 328 U.S. 217, 227 (1946) (Frankfurter, J., dissenting)).

158. Id. at $529 \& \mathrm{n} .7$ (quoting with approval a House Report on the Jury Selection and Service Act of 1968, H.R. REP. No. 90-1076, at 8 (1968), reprinted in 1968 U.S.C.C.A.N. 1797).

159. Id. at 530.

160. See Massaro, supra note 146, at 512 ("Popular participation in criminal trials also serves community interests... Juries ... satisfy the community's desire to participate in, and consequently to effect some control over, the criminal justice system. The jury interjects community conscience into the process, if only symbolically."). 
privilege of jury duty is their most significant opportunity to participate in the democratic process. ${ }^{161}$

The Supreme Court has also suggested myriad ways in which juries improve the quality of criminal justice, many of which hinge directly on community involvement. One broad way that juries improve the criminal justice system is simply by providing twelve different human perspectives on the evidence and thus improving the quality of the ultimate verdict. ${ }^{162}$

Perhaps one of the most compelling functions of the jury is to serve as one of the "checks and balances" in American governance. ${ }^{163}$ The jury guards against official corruption by pulling together a group of citizens and empowering them to watch over the work of the prosecutor and the judge. ${ }^{164}$ The jury interposes the "common sense judgment" of the community between the defendant and powerful government officials. ${ }^{165}$ For many of these reasons, the Supreme Court held in Duncan v. Louisiana ${ }^{166}$ that juries are fundamental to our system of ordered liberty and that the Fourteenth Amendment's due process provision incorporates the right to a trial by jury and thus requires state courts to provide juries.

Another major function that juries serve is overtly political and it goes in two directions. Just as communities, through juries, affect the administration of criminal justice, the criminal justice system uses the jury to educate the public and to ensure the legitimacy of the system. Jury duty "educates citizens in the mechanics of their justice system." 167 Juries ensure "public confidence in the fairness of the criminal justice system"168 and ensure pub-

161. Powers v. Ohio, 499 U.S. 400, 406-07 (1991) (quotation marks and citations omitted). Given the rhetoric of Supreme Court cases, one can easily see why some of the members of Congress who favored passage of the Major Crimes Act thought that participation in federal criminal justice might have the effect of "civilizing" and assimilating the Indians. The problem is that adoption of the Major Crimes Act did not come hand-in-hand with Indian participation on federal juries or in any role in the judicial process, other than as defendants.

162. Taylor, 419 U.S. at 535 (discussing the "quality of community judgment represented by the jury in criminal trials").

163. Duncan v. Louisiana, 391 U.S. 145, 155-56 (1968).

164. Id. at 155 . By placing the ultimate decisionmaking powers in the jury, the existing structure guards against corruption of judicial officers. See AKHIL ReEd AMAR, THE CONSTitution AND Criminal Procedure: First Principles 121 (1997) (citing The Federalist No. 83 (Alexander Hamilton)).

165. See Massaro, supra note 146 , at 510.

166. 391 U.S. 145 (1968).

167. Massaro, supra note 146, at 515; see also Powers v. Ohio, 499 U.S. 400, 400 (1990); Nancy J. King, Postconviction Review of Jury Discrimination: Measuring the Effects of Juror Race on Jury Decisions, 92 Mich. L. REv. 63, 115 (1993) ("In addition, because jury trials educate jurors in self-governance, deterring discriminatory jury selection practices helps to ensure that all citizens have an equal opportunity for the civic education jury service provides." (citation omitted)); Massaro, supra note 146, at 515 ("A powerful reminder of the educational aspect of jury trials is the positive reaction many citizens have to their service as jurors. Moreover, to the extent their encounter with the justice system increases jurors' respect for judgments, it preserves government power." (citation omitted)).

168. Taylor v. Louisiana, 419 U.S. 522, 530 (1975). 
lic acceptance of judicial outcomes. ${ }^{169}$ They "satisfy the community's desire to participate in, and consequently to effect some control over, the criminal justice system." ${ }^{170}$ It is for this reason that some Justices would even hold that the Eighth Amendment proscription on cruel and unusual punishment contains an implicit principle that capital punishment may be imposed only by a jury and not by a judge; the jury has a "comparative advantage" over the judge in expressing "the community's moral sensibility" and is more likely to "express the conscience of the community."171

\section{B. Representative Juries and Anti-Discrimination in Jury Composition}

Because of the key role that the jury plays in representing the community, the Supreme Court began addressing racially discriminatory jury composition soon after the Civil War. In Strauder v. West Virginia ${ }^{172}$ in 1879 , the Supreme Court overturned a black man's murder conviction because the state had explicitly excluded blacks from serving on the jury, holding that the Fourteenth Amendment's Equal Protection Clause prohibits exclusion of black jurors from juries in state courts. The Court discussed two different types of rights in its decision. First, it recognized that the black community has a "right to participate in the administration of the law" that may not be denied through racially discriminatory state laws. ${ }^{173}$ Second, the Court recognized the right of the black defendant to a trial by a jury selected without discrimination against others of his race. ${ }^{174}$

The very next year, in Neal v. Delaware, the Supreme Court held that even de facto discrimination was actionable. ${ }^{175}$ In that case, even though Delaware's law was not explicit in excluding blacks, the Supreme Court overturned a black defendant's rape conviction on the basis of de facto discrimination in light of evidence establishing that a black person had never served on a jury in the entire state of Delaware. ${ }^{176}$ In other words, the jury's representative role was so important that the Court was willing to protect it against even possibly accidental and unintentional actions that diminished the jury's representativeness.

169. See id.; see also Nancy J. King, Racial Jurymandering: Cancer or Cure? A Contemporary Review of Affirmative Action in Jury Selection, 68 N.Y.U. L. Rev. 707, 751 (1993) (suggesting that a goal of race-conscious jury selection is that "it enhances public respect for criminal proceedings and acceptance of their results"); Massaro, supra note 146, at 517 ("[J]ury selection procedures must produce juries that correspond to people's images of a fair jury. Otherwise, people will distrust jury verdicts regardless of the 'correctness' of those results on the merits, and the jury will lose the respect essential to effective decision making.").

170. Massaro, supra note 146 , at 512.

171. Ring v. Arizona, 536 U.S. 584, 613-14 (2002) (Breyer, J., concurring) (citing Justice Stevens's dissent in Harris v. Alabama, 513 U.S. 504, 515-26 (1995)).

172. 100 U.S. 303 (1880).

173. Strauder, 100 U.S. at 308; see also KENNEDY, supra note 153, at 169-71.

174. Strauder, 100 U.S. at 309.

175. 103 U.S. 370 (1881).

176. Neal, 103 U.S. at 370. 
During the next century, the Court's jurisprudence on juries expanded tremendously. In the 1930s, the Court used the precedent in Neal v. Delaware to overturn convictions of black defendants in an Alabama county in which no living person could remember a black person ever serving on a jury ${ }^{177}$ and in a Kentucky county in which no black person had served in the previous thirty years. ${ }^{178}$

In 1968, during the civil rights movement, Congress enacted a law governing the selection of federal juries that codified much of the antidiscrimination jurisprudence enunciated by the Supreme Court in these cases and others. The Jury Selection and Service Act ("JSSA") now provides the basic legal rules that apply to jury selection in federal cases, including those arising in Indian country. The JSSA generally provides that all litigants in federal courts who are entitled to trial by jury "shall have the right to grand and petit juries selected at random from a fair cross section of the community."

While the statutory rules for jury selection apply in both civil and criminal cases, the Supreme Court has elevated the JSSA's rules to constitutional status in criminal cases, holding that the Sixth Amendment guarantee of an "impartial" jury means a jury that is selected from a venire that constitutes a "fair cross section of the community." Despite the statutory guidance in the JSSA, Supreme Court case law continues to inform the analysis substantially.

In Duren v. Missouri, ${ }^{182}$ the Supreme Court set forth an analytical approach to determine whether the fair cross section requirement was violated. To prove such a claim, the defendant must establish:

(1) that the group alleged to be excluded is a distinctive group in the community; (2) that the representation of this group in venires from which juries are selected is not fair and reasonable in relation to the number of such persons in the community; and (3) that this underrepresentation is due to systematic exclusion of the group in the jury-selection process. ${ }^{183}$

While the requirement of a fair cross-section does not extend to the final composition of the jury, ${ }^{184}$ racial discrimination in the selection of the jury is

177. Norris v. Alabama, 294 U.S. 587 (1935).

178. Hale v. Kentucky, 303 U.S. 613 (1938).

179. 28 U.S.C. $\S \S 1861-1869(2000)$.

180. 28 U.S.C. $\$ 1861$ (2000).

181. See Holland v. Illinois, 493 U.S. 474, 477 (1990); Duren v. Missouri, 439 U.S. 357, 364 (1979); Taylor v. Louisiana, 419 U.S. 522, 528 (1975). Because federal law does not distinguish between the methods of selection of the pools from which grand or petit juries are chosen and the similar community representative purposes of each type of jury, the courts have treated issues as to the selection of either type of jury similarly. See generally 28 U.S.C. $\S \S 1861-1869$ (2000)).

182. Duren, 439 U.S. 357 (1979).

183. Id. at 364 (internal quotations omitted).

184. Taylor, 419 U.S. at 538; see also Holland, 493 U.S. 474 (1990). In Holland, the Court indicated that the Sixth Amendment requires a venire that is representative of the community so that a jury will be "drawn from a representative cross section of the community," id. at 480 (quoting 
considered an unconstitutional "harm" to the "entire community" that "undermine[s] public confidence in the fairness of our system of justice." "85

Focusing primarily on African Americans, Professor Randall Kennedy has addressed many of the problems related to underrepresentation of members of minority groups on juries. As Kennedy has explained, the failure to include African Americans on juries regarding crimes that affect their communities can have serious practical ramifications. ${ }^{186} \mathrm{~A}$ community denied its proper role in the criminal justice system may feel aggrieved and may seek justice by other means. Consider, for example, the trial against white police officers accused of beating African American Rodney King, which was moved out of Los Angeles to Simi Valley, a predominantly white suburb. When the Simi Valley jury returned not guilty verdicts on the most serious charges, members of the black community in Los Angeles perceived a miscarriage of justice. The ensuing riot was the most destructive in the United States in the twentieth century, culminating in fifty-two deaths, thousands of injuries, and nearly a billion dollars of property damage ${ }^{187}$ In any event, positive law in the United States has created general rules that ensure the Rodney King case is exceptional. American law is generally protective of the jury's community-representative role in criminal justice.

\section{Underrepresentation of Native Americans on Indian Country Juries}

Despite the normative principle of representativeness, Indians tend not to be well represented in federal juries in Indian country cases. Even in states with large Indian populations, Indians remain a very small fraction of the population. ${ }^{188}$ As a result, Indians would be expected to have minimal representation in the jury venire. However, the statistics indicate lower numbers than one would expect. Underrepresentation even of the existing small fraction of the population may occur for a variety of reasons. First, Indians are among the poorest Americans. ${ }^{189}$ Because juries in most federal

Taylor, 419 U.S. at 527), but that “[ $\mathrm{t}]$ he 'representativeness' constitutionally required at the venire stage can be disrupted" for good reason while empanelling the jury through the exercise of peremptory and cause strikes against particular members, id. at 483 .

185. Batson v. Kentucky, 476 U.S. 79,87 (1986).

186. KENNEDY, supra note 153, at 117-18.

187. Id.; see also Koon v. United States, 518 U.S. 81 (1996). Such civil unrest may be effective in gaining the attention of policymakers in ways that mere case law cannot.

188. Even in the states with the largest percentages of American Indians, Indians account for less than twenty percent of the total population and usually less than ten percent. See STELLA U. Ogunwole, U.S. Dep't of Commerce, U.S. Census Bureau, Census 2000 Brief: The AmeriCan Indian and Alaska Native Population: 2000, at 5 (2002).

189. Yair Listokin, Confronting the Barriers to Native American Home Ownership on Tribal Lands: The Case of the Navajo Partnership for Housing, 33 URB. LAw. 433, 434-35 (2001) ("Indians are among the poorest Americans. In 1990, almost one third (31.2 percent) lived in povertymuch higher than the 1990 national 13.5 percent poverty rate." (citation omitted)); see also Russel Lawrence Barsh, The Challenge of Indigenous Self-Determination, 26 U. MiCH. J.L. REFORM 277 , 287 (1993) (declaring Indians to be "among the poorest Americans"). 
districts are chosen from state voter rolls, ${ }^{190}$ "federal jury venires underrepresent the poor" who are less likely to register to vote and, even if they have registered, are more likely to have moved since they last registered. ${ }^{19}$

Even aside from poverty, Indians may well have lower representation in the potential pool than their small absolute numbers might forecast. Indians are, for example, likely to be far more invested in their tribal governments than state governments. ${ }^{192}$ Since juries are routinely selected from voter registration lists of state political subdivisions, even relatively politically active and aware tribal members may nevertheless not be represented if they focus their activism solely within the tribal government. While the JSSA seems to allow use of tribal voting registration lists, it does not require such use. ${ }^{193}$

Perhaps most important, however, is the geographic aspect of the problem. The federal districts that include Indian reservations are physically among the largest in the United States. ${ }^{194}$ Because of the tremendous sizes of the districts, each judicial district is divided into multiple divisions. Most federal courts are located in larger cities, and they tend to assemble jury venires from the division in which they sit. And even if the court attempts to assemble juries from a division that includes Indian reservations, the trial may well be held in an even more distant location in another division. ${ }^{195}$

190. See Jury Selection and Service Act of 1978, 28 U.S.C. $\$ 1863(b)(2)$ (2000) (indicating that each federal district must create its own plan for jury selection and indicating that such plan shall use voter registration records or lists of actual voters from political subdivisions within the state); see also King, supra note 169, at 712-17 (discussing some of the factors-for example, unrepresentative voter registration lists, mobility of population, educational history-that make minorities less likely to be represented fairly in jury pools).

191. Mitchell S. Zuklie, Comment, Rethinking the Fair Cross-Section Requirement, 84 CAL. L. REv. 101, 103-04 (1996) (collecting studies across the country concluding that the poor are underrepresented).

192. Some Indians feel that the unilateral extension of American citizenship to them without their consent was an act of "cultural genocide." See, e.g., Robert B. Porter, The Demise of the Ongwehoweh and the Rise of the Native Americans: Redressing the Genocidal Act of Forcing American Citizenship upon Indigenous Peoples, 15 HaRv. BlackLetTER L.J. 107 (1999). It would be fair to assume that many Native Americans holding these views might not register to vote in federal or state elections.

193. The JSSA allows the names of prospective jurors to be selected from the "voter registration lists or the lists of actual voters of the political subdivisions within the district or division." 28 U.S.C. \$ 1863(b)(2); see also United States v. Bushyhead, 270 F.3d 905, 909-10 (9th Cir. 2001) (describing the Nevada federal jury selection plan as using the voter registration information only of state and county offices and not of tribal governments).

194. There are ninety-four federal judicial districts in the United States and one United States Attorney for each judicial district. From a geographical standpoint, the largest federal judicial districts are, in descending order, the Districts of Alaska, Montana, New Mexico, Arizona, and Nevada. The states of Arizona, Montana, Nevada, New Mexico, and South Dakota are each comprised of a single statewide federal judicial district and each includes substantial Indian country jurisdiction. The United States Attorney's Office in Alaska, which has very little Indian country jurisdiction, has approximately twenty Assistant United States Attorneys in total and a small number of support staff. U.S. Attorney's Office, District of Alaska, http://www.usdoj.gov/usao/ak/info/administrative.htm (last visited Nov. 27, 2005). In Arizona, in contrast, Indian country makes up nearly twenty percent of the land mass within the state. And in contrast to the small office in Alaska, the United States Attorney's Office in Arizona has approximately 275 employees. U.S. Attorney's Office, District of Arizona, http://www.usdoj.gov/usao/az/index.html (last visited Aug. 24, 2005).

195. See United States v. Nakai, 413 F.3d 1019 (9th Cir. 2005). 
Reservations are often located at great distances from the principle cities where federal courts sit.

Consider, for example, the federal District of Arizona. In Arizona, the Navajo reservation sends more cases to the United States Attorney's Office than all other tribes in the state combined. ${ }^{196}$ Federal trials of these cases routinely occur in Prescott or Phoenix. As the figure below indicates, Prescott is around one hundred miles, as the crow flies, from the closest point on the Navajo Reservation and more than two hundred miles from the heart of that reservation. By highway, these distances are much greater.

FigURE I

Arizona Indian Reservations and District Court Venues

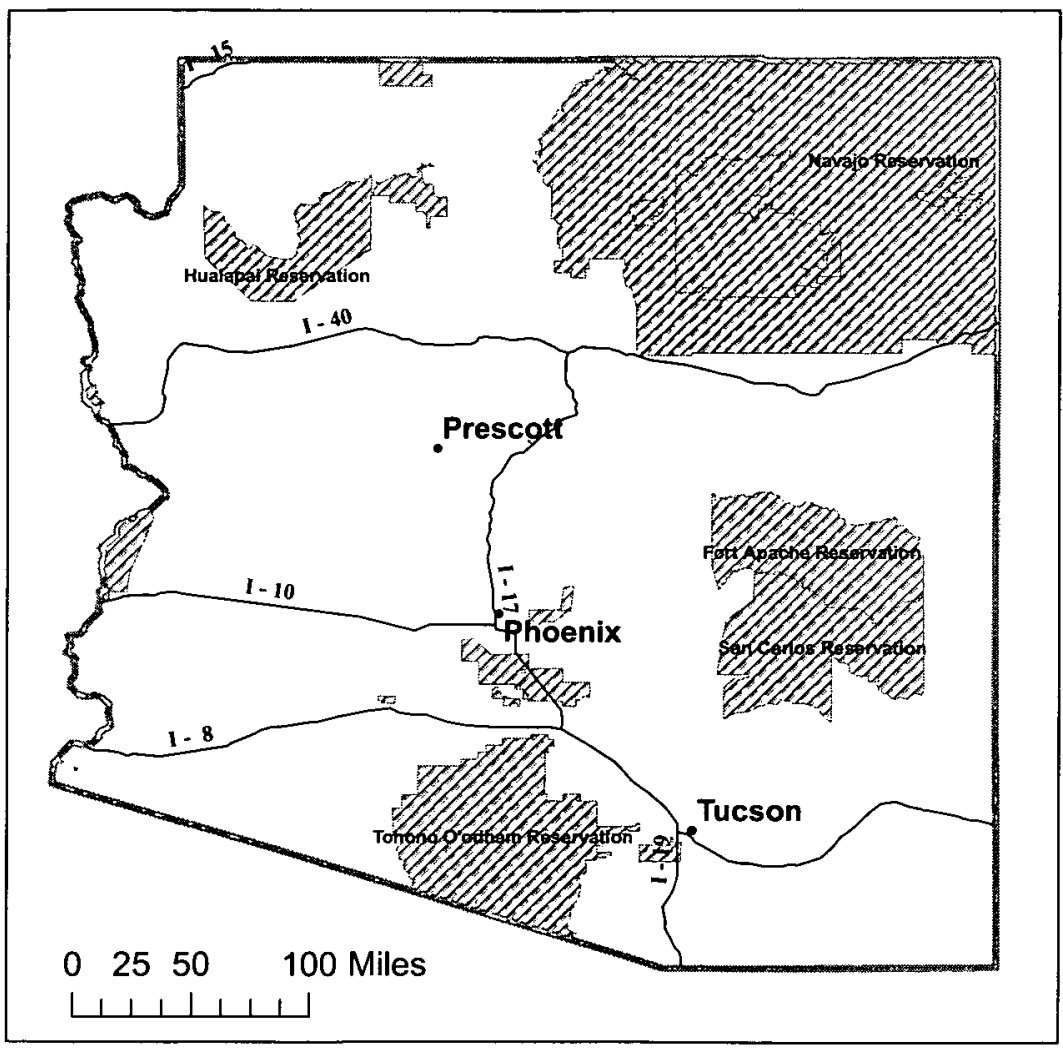

196. Paul K. Charlton, U.S. Attorney's Office for the District of ARiz., U.S. Dep't OF JUSTICE, 2004 INDIAN COUNTRY REPORT 64-69 (2004), http://www.usdoj.gov/usao/az/reports/ 2004rpt/azusao.pdf. 
Now consider the federal District of Minnesota. Though Minnesota is somewhat smaller than Arizona, ${ }^{197}$ the geographic reality is similar. All of the federal Indian country offenses in Minnesota originate on two reservations, the Red Lake Reservation and the Bois Fort Reservation in the northern part of the state. The federal criminal trials for these reservations routinely occur in the so-called Twin Cities of Minneapolis and St. Paul, which is where all of the federal district court judges' chambers are located. ${ }^{198}$ As the figure below indicates, both reservations lie a tremendous distance from the Twin Cites, and the Red Lake reservation, which produces the vast majority of the federal Major Crimes cases in the district, is particularly remote from major highways, making it difficult to reach.

As a result of the geographic factors and the other phenomena mentioned previously, Native Americans are poorly represented on all federal jury panels. Because juries in Indian country cases are selected in the same manner as all other federal criminal juries, Indians are almost never wellrepresented as jurors in Indian country cases. In that sense, they share many of the traditional complaints of other minority communities related to the composition of juries. ${ }^{199}$

197. Arizona at approximately 114,000 square miles is almost half again as large as Minnesota which encompasses less than 80,000 square miles. Rand McNally \& Co., The Road AtLaS '05, at 8,54 (2005).

198. See U.S. District Court, District of Minn., http://www.mnd.uscourts.gov (last visited Nov. 13, 2005).

199. Cf. Laura G. Dooley, The Dilution Effect: Federalization, Fair Cross-Sections, and the Concept of Community, 54 DePaul L. REv. 79, 80-81 (2004) (arguing that federal juries do not properly represent communities in urban drug offense cases because the federal jury is drawn differently than a jury that would be drawn under state law for a state prosecution); see also Paul Butler, Racially Based Jury Nullification: Black Power in the Criminal Justice System, 105 YALE L.J. 677 $(1995)$. Some cases have also addressed similar issues. E.g., United States v. Osorio, 801 F. Supp. 966, 979-80 (D. Conn. 1992) (defendant's challenge to a jury venire that excluded jurors from two of the most populous and most minority-dense cities from the venire). 
FIGURE 2

\section{Minnesota Indian Reservations Under Federal JuRisdiction}

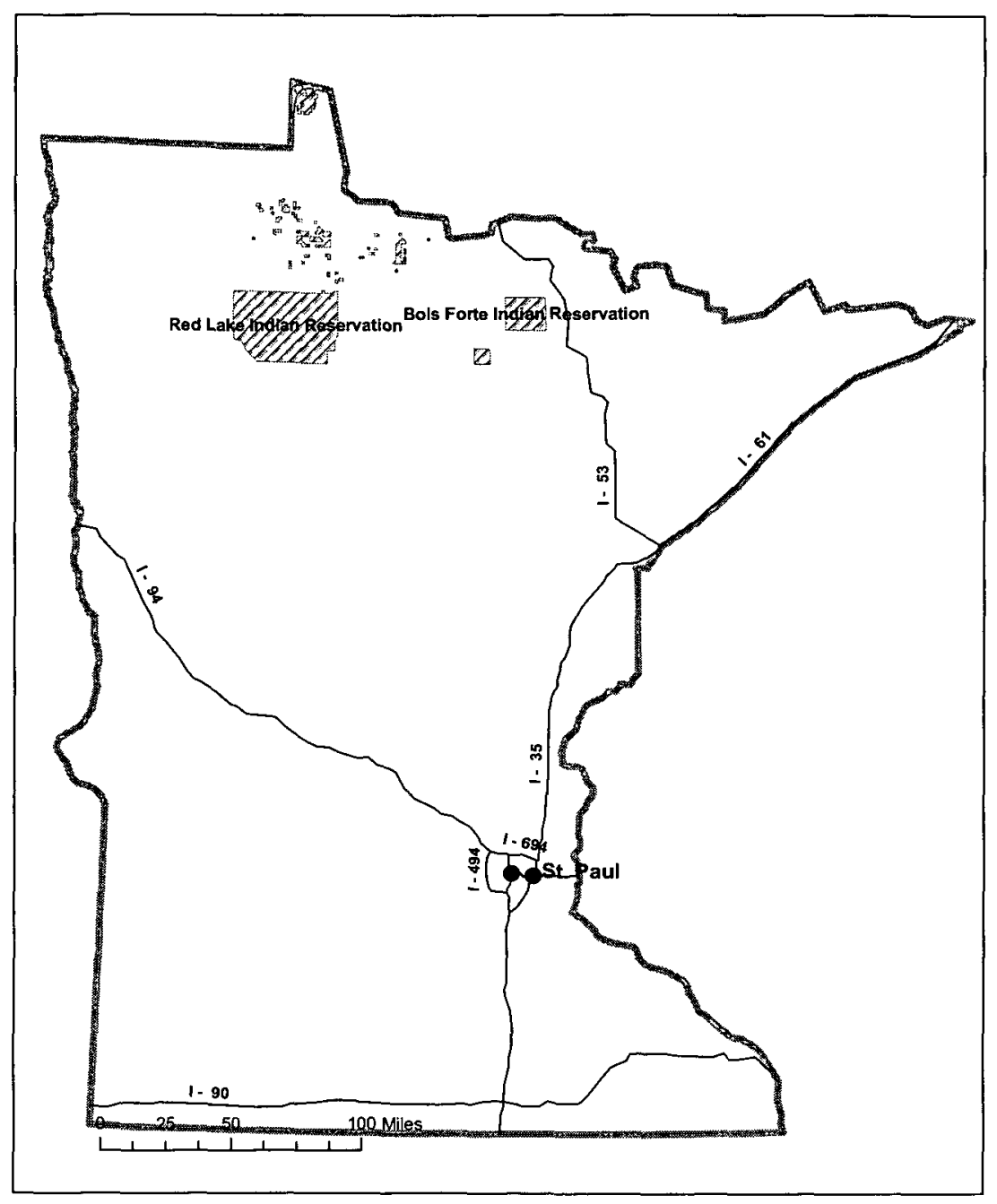

\section{Legal Challenges}

Drawing upon the legal principles set forth in Duren v. Missouri, defendants in Indian country cases have challenged jury pool composition in a variety of circumstances as being underrepresentative of Native Americans. ${ }^{200}$

200. Cf. United States v. Gault, 141 F.3d 1399 (10th Cir. 1998); United States v. Erickson, 75 F.3d 470 (9th Cir. 1996); United States v. Herbert, 698 F.2d 981 (9th Cir. 1983); United States v. Haworth, 948 F. Supp. 981 (D.N.M. 1996); United States v. Pleier, 849 F. Supp. 1321 (D. Alaska 
In an early Eighth Circuit case, United States v. Clifford ${ }^{201}$ the defendant presented evidence that Indians living within the division from which the trial jury was selected constituted $15.6 \%$ of the total populace, but that only $8.4 \%$ of the jurors who served during a two-year period were Indian. This evidence demonstrated an "absolute disparity" (the difference between the figures) of $7.2 \%$ and a "comparative disparity" of $46 \%{ }^{202}$ In other words, each jury had, on average, $46 \%$ fewer Indians than it would have had if its composition matched the representation of Indians in the general population.

Following an analysis that generally tracked the three-step Duren approach, ${ }^{203}$ the Eighth Circuit recognized that Indians are a "distinctive group" that should be represented in a fair cross-section of the community. ${ }^{204}$ However, the Eighth Circuit held that the underrepresentation failed Duren's second factor, which asks whether the group's representation is "fair and reasonable in relation to the number of such persons in the community." 205 The court held that the disparity established by the evidence was not substantial enough as a matter of law to constitute a violation of the JSSA or the Sixth Amendment. ${ }^{206}$ Accordingly, the defendant was unable to establish a prima facie violation and was unable even to reach the third step of showing that the underrepresentation was due to "systematic exclusion." Since that time, other challenges in the Eighth Circuit have been equally unsuccessful. ${ }^{207}$

The Tenth Circuit first addressed the issue at about the same time and reached a similar result. In United States v. Yazzie, ${ }^{208}$ an Indian defendant presented evidence that the proportion of Indians in the grand jury was $45 \%$ lower than the proportion of Indians over age eighteen in the general population of the state. ${ }^{209}$ The defendant also presented evidence that the proportion of jurors on the petit jury was $46 \%$ lower than the proportion of Indians in the general population over age eighteen in the division from which the jury was drawn. ${ }^{210}$ The Tenth Circuit in Yazzie, like the Eighth Circuit in Clifford, held that such disparities were not substantial enough to

1994). Because this Article is directed at cases prosecuted under the Major Crimes Act and not general federal laws, this Article will focus on cases that present the issue in Indian country.

201. 640 F.2d 150 (8th Cir. 1981).

202. Clifford, 640 F.2d at 154-55.

203. See supra note 183 and accompanying text.

204. Clifford, 640 F.2d at 154-55.

205. Id. (citing Duren v. Missouri, 439 U.S. 357, 364 (1979)).

206. Id. at $155-56$.

207. See United States v. Greatwalker, 356 F.3d 908 (8th Cir. 2004); United States v. Ireland 62 F.3d 227 (8th Cir. 1995); United States v. Grey Bear, 883 F.2d 1382 (8th Cir. 1989); United States v. Black Bear, 878 F.2d 213 (8th Cir. 1989); Peltier v. United States, 867 F.2d 1125 (8th Cir. 1989).

208. 660 F.2d 422 (10th Cir. 1981).

209. Yazzie, 660 F.2d at 427.

210. Id. 
demonstrate that the venire was "not [a] fair and reasonable" representation of the community." Just as in the Eighth Circuit, no Indian country defendant in the Tenth Circuit has ever successfully challenged jury composition on such a basis. ${ }^{212}$

The issue has also arisen regularly in the Ninth Circuit. In United States v. Etsitty, ${ }^{213}$ a Navajo defendant challenged the transfer of a jury trial from the District of Arizona's Prescott Division of the court to the Phoenix Division on the basis that the transfer "deprived him of a jury venire that reflected the large percentage of Indians in the Prescott Division." ${ }^{214}$ According to the court, the crimes occurred "within the territory of the Prescott Division," and the Prescott Division "contains several Indian reservations, and consequently a far higher percentage of Native Americans than the Phoenix Division." ${ }^{215}$ The Ninth Circuit noted that judges have tremendous discretion to transfer cases within the district and that the jury selection plan in the Phoenix Division fairly represents that division's population. ${ }^{216} \mathrm{De}-$ spite the fact that the court had a local rule providing that all cases arising in either the Prescott or Phoenix Division would be tried in Phoenix, the court held that the defendant had not presented sufficient evidence of a systematic transfer of cases from the Prescott Division to the Phoenix Division resulting in the exclusion of Indian jurors because the defendant failed to establish that the local rule was applied. ${ }^{217}$ However, the court noted that the systematic removal of cases from the Prescott Division to the Phoenix Division would present a strong case for finding a systematic exclusion of Indians under Duren $v$ Missouri. ${ }^{218}$ Thus, the court indicated that such a practice, if established, would amount to an abuse of discretion. ${ }^{219}$

Given the clear language in Etsitty, it was not long before the issue arose again in a case with a stronger evidentiary record. In United States v. Footracer, ${ }^{220}$ the district court had transferred the Navajo defendant's trial from Prescott to Phoenix; the district court then denied the defendant's motion to move the trial back to Prescott. The defendant argued on appeal that the transfer of his case from Prescott to Phoenix denied him a jury panel composed of a fair cross section of the community. ${ }^{221}$ He presented evidence indicating that Native Americans constituted $20.78 \%$ of the population over

211. Id.

212. See, e.g., United States v. Pino, 708 F.2d 523 (10th Cir. 1983).

213. United States v. Etsitty, 130 F.3d 420 (9th Cir. 1997), amended by 140 F.3d 1274 (9th Cir. 1997).

214. Etsitty, 130 F.3d at 424.

215. Id. at 424-25.

216. Id. at 425 .

217. Id. at 425-26.

218. Id.

219. Id. at 425 .

220. 189 F.3d 1058 (9th Cir. 1999), withdrawn, 252 F.3d 1059 (9th Cir. 2001).

221. Footracer, 189 F.3d at 1060. 
the age of eighteen in the Prescott Division, but only $1.73 \%$ of the population over the age of eighteen in the Phoenix Division. ${ }^{222}$ The Ninth Circuit once again found that the third prong of Duren was not met. ${ }^{223}$ The court departed, however, from the approach it had used in Etsitty and characterized the key language in that case as dictum. Instead, it held that there was no systematic exclusion of Indians from the jury venire because the move from Prescott to Phoenix systematically excluded all residents of the Prescott Division, not just Indians: "Native Americans are not treated differently; they are excluded to the same extent as all other racial and ethnic groups in the Prescott Division., 224

A vigorous dissent by Judge Pregerson excoriated the majority for ignoring its warning in Etsitty and for "importing the equal protection concept of discriminatory intent into what is a straightforward Sixth Amendment fair cross-section challenge." ${ }^{225}$ A petition for rehearing was filed and the opinion was withdrawn almost two years later. ${ }^{226}$ Meanwhile, shortly after Etistty, the federal district court in Arizona amended its local rules to provide that cases arising in the Prescott Division will be tried in Prescott. ${ }^{227}$ The rule change presumably prevents a repeat of the issue in that district.

The "fair cross-section" issue arose again the Ninth Circuit in United States v. Bushyhead. ${ }^{228}$ The defendant, an Indian prosecuted for a murder on the Pyramid Lake Paiute Reservation in northern Nevada, argued that his conviction should be reversed because he was denied a panel constituting a "fair cross-section" of the community; the jury selection plan in the District of Nevada drew only from county voting lists and not from tribal voting lists. ${ }^{229}$ The Ninth Circuit rejected Bushyhead's argument. The JSSA generally authorizes the district court to select the political subdivisions from which it will obtain voting lists. ${ }^{230}$ It seems to allow, but does not require, the district court to select among other appropriate subdivisions of government from which it will draw lists. ${ }^{231}$ The Ninth Circuit noted that people living on reservations in Nevada also live within Nevada counties and thus are not purposefully excluded from the county voting lists; they may register for

222. Id. at 1066 n. 1 (Pregerson, J., dissenting).

223. Id. at $1061-62$.

224. Id.

225. Id. at 1067 (Pregerson, J., dissenting).

226. Footracer, 252 F.3d 1059, 1059 (9th Cir. 2001). The opinion was replaced with an unpublished memorandum disposition that rejected the defendant's arguments with little analysis. United States v. Footracer, 16 F. App'x 595, 595-96 (9th Cir. 2001) (unpublished op.). The withdawal of the opinion surely reflects problems with the court's original analysis of this issue.

227. Rules of Practice of the U.S. Dist. CT. FOR THE Dist. Of ARIz. 1.1(c) (2003) (rule relocated to 77.1 (c) in 2004).

228. United States v. Bushyhead, 270 F.3d 905, 907 (9th Cir. 2001).

229. Id. at 909 .

230. Id. at 910 ; see 28 U.S.C. $\$ 1863(\mathrm{~b})(2)(2000)$.

231. 28 U.S.C. $\$ 1863(b)(2)$. 
elections like any other citizens within those counties. ${ }^{232}$ Therefore, the court held that Bushyhead could not establish that the jury selection plan was not fair or reasonable under Duren's second prong or that it caused "systematic exclusion" of Native Americans under the third prong. ${ }^{233}$ Thus, the Ninth Circuit joins the Eighth and Tenth Circuits in never having entertained a successful challenge by an Indian to an Indian country prosecution for lack of a jury constituting a "fair cross-section" of the community. Together these three circuits make up the vast majority of Indian country jurisdiction in the United States.

\section{E. A Critique of Jury Composition Cases in Indian Country}

In each of the challenges discussed above, the parties argued that the jury pools failed to constitute representative cross-sections of the community because they excluded Native Americans. ${ }^{234}$ The parties and the courts have made three general types of analytical errors in these cases.

\section{Representativeness and a Jury of One's Peers}

First, in using the standard developed in Duren v. Missouri, the courts and the litigants have lost sight of one of the original principles that animated Strauder: "[t]he very idea of a jury is a body of men composed of the peers or equals of the person whose rights it is selected or summoned to determine; that is, of his neighbors, fellows, associates, persons having the same legal status in society as that which he holds." ${ }^{235}$

In Indian country cases, obtaining jurors from the entire district results in using jurors from outside the Indian country jurisdiction of the court. Although neither the Constitution nor the Sixth Amendment use the term "peers," the Supreme Court has, from time to time indicated that the right to trial by jury means a right to a jury of one's peers. ${ }^{236}$ Since the term is not explicitly constitutional, it has never been effectively defined, at least for federal purposes. ${ }^{237}$ However, the Court has suggested that the term is implicit within the definition of jury and that the term means to include only those persons with the same legal status as the defendant, those who live

\section{Bushyhead, 270 F.3d at 910 .}

233. Id. at 909-10.

234. See, e.g., id. at 907; United States v. Footracer, 189 F.3d 1058, 1061 (9th Cir. 1999), withdrawn, 252 F.3d 1059 (9th Cir. 2001); United States v. Yazzie, 660 F.2d 422, 426-28 (10th Cir. 1981) (finding no underrepresentation of Indians on jury venires); $c f$. United States v. Raszkiewicz, 169 F.3d 459, 462-67 (7th Cir. 1999) (rejecting non-Indian defendant's claim in a federal bank robbery case that the jury did not represent a fair cross-section of the community because, though it included "urban Indians," it did not include "reservation Indians").

235. Strauder v. West Virginia, 100 U.S. 303, 308 (1880) (emphasis added).

236. See id.; Apodaca v. Oregon, 406 U.S. 404, 411 (1972); see also Massaro, supra note 146, at 548 ("Although the United States Constitution makes no mention of 'peers,' most people believe the Constitution entitles them to a "jury of their peers.").

237. See Massaro, supra note 146, at 548-50. 
within the reach of the same laws. ${ }^{238}$ Since no off-reservation person can be prosecuted for an Indian country offense unless he ventures into Indian country and commits a crime, the average juror in an Indian country case is simply not in any practical sense a "peer" to the defendant in the case. ${ }^{239}$ Such a scheme is thus arguably contrary to the broader principle enunciated in Strauder that a person should be judged by persons subject to the same laws. ${ }^{240}$

\section{Considering the Indian Law Context of These Cases}

Litigants and the courts have also failed to give proper consideration to the Indian law context of these cases. As the Supreme Court recognized when it first upheld the Major Crimes Act, "[Indians] owe no allegiance to the States, and receive from them no protection. Because of the local ill feeling, the people of the States where they are found are often their deadliest enemies."241 Given that one of the justifications for the Indian country criminal justice regime is the federal government's duty of protection toward Indians and, often, as against state authority (and state authorities), how can state voter registration lists be the appropriate resources for creating a jury pool? In other words, why should federal courts look to the people whom the Supreme Court once described as the Indians' "deadliest enemies" to construct a jury pool that is impartial for purposes of the Sixth Amendment?

Viewed in this light, the defendant's argument in Bushyhead was, in many ways, the most insightful. The facts supporting this case were far stronger than the Ninth Circuit recognized. In general, although the participation of Indians in state elections seems to be growing, ${ }^{242}$ Indians can be expected to be far more invested in their tribal governments than in state governments. On Indian reservations, tribal governments are often more salient than state governments. Tribal governments often provide numerous services, such as medical and dental care, social services, schools and education, and law enforcement. In other words, the existence of tribal

\section{Strauder, 100 U.S. at 308.}

239. For a discussion about the importance of the inclusion of peers on a jury, see Massaro, supra note 146 , at 552 . Massaro finds that " $[\mathrm{t}]$ he idea behind the peer concept . . is to assure empathy, not sympathy, for the accused. Empathy in this sense means the capacity for participating in or vicariously experiencing another's feelings, volitions, or ideas. It is a form of understanding." Id. She continues, "A jury that includes the defendant's peers-people who are able to identify with the defendant and his experiences-may view the prosecution's case very differently than would a jury of people who are merely 'impartial' or who are peers of the alleged victim." Id.

240. Indeed, the Ninth Circuit's assertion in United States v. Footracer that "Native Americans are ... excluded [only] to the same extent as all other racial and ethnic groups in the Prescott Division," 189 F.3d 1058, 1061 (9th Cir. 1999), withdrawn, 252 F.3d 1059 (9th Cir. 2001), harkens back to Justice Field's dissent in Strauder, which plaintively explained that the black defendant in that case received a fair jury because he received exactly the same type of jury (twelve white males) that any white defendant received. Strauder, 100 U.S. at 312 (Field, J., dissenting) (citing his own dissent in Ex parte Virginia, 100 U.S. 339, 349-70 (1880)). Such an approach thus seems patently inconsistent with the plain meaning of the majority opinion in Strauder.

241. United States v. Kagama, 118 U.S. 375, 384 (1886).

242. See generally LaVelle, supra note 96. 
governments tends to undermine the importance of local and state governments. Tribal governments tend to provide even more services than state and local governments routinely provide to their own constituents. It is only natural that Indians have greater interest in their governments than in state governmental institutions. Thus, tribal citizens may not have as much reason to participate in state elections and voting.

While one might criticize Indians for "opting out" of their right to participate in the state electoral processes, the Indian country criminal justice regime implicitly condones the notion that Indians need not participate in state electoral politics. Indeed, federal law creates criminal jurisdiction that is exclusively federal and tribal and thus serves to shield Indians from the influence of state officials. Under such circumstances, Indians might be expected to opt out of state and local elections for officials who have little or no impact on their lives. The Major Crimes Act and other federal laws like it are designed to preserve a separate existence for Indian tribes. Indeed, they presume to preserve each tribe's right to remain alienated from the state body politic. To some degree, the very purpose of an Indian reservation is to provide a refuge from state governments. ${ }^{243}$ Given this underlying rationale for Indian reservations, it is curious that federal courts would look to state voter rolls to find jurors. It undermines the very nature of a reservation as a sanctuary from state authority.

\section{Focusing on "The Community"}

Perhaps the most important error that the litigants and courts have made in these cases, however, is failing to use the basic theory of Duren properly by failing to focus on the proper legal principles. In focusing on "fair crosssection," each of these challenges has simply argued the wrong point. Attempting to achieve "a fair cross-section of the community" begs the most important question: what community?

While the routine approach to jury selection may be legitimate in the context of general federal criminal laws, the Indian country laws are not federal laws of general applicability with nationwide application. Indian country prosecutions are not brought to protect the national "community." They are brought to protect the Indian reservation community. Thus, a jury pool that represents a fair cross-section of the judicial district or a division thereof will not constitute a cross-section, fair or otherwise, of the Indian country community. And it is only the existence of the crime within the Indian country community that justifies federal jurisdiction.

In Clifford, Etsitty, Yazzie, and even to some degree in Bushyhead, the defendants tried to shoehorn otherwise strong arguments into the wrong portion of the reasoning of Duren v. Missouri. In insuring a fair crosssection of the community on the jury panel, Duren v. Missouri sought not to

243. Cf. Bryan v. Itasca County, 426 U.S. 373, 389 (1976) (explaining that not even Public Law 280 was intended "to subject reservation Indians to the full sweep of state laws and state taxation"). 
seek diversity for diversity's sake, but sought to ensure representativeness of the community so as to protect the community's central role in criminal justice. ${ }^{244}$

While Duren was attempting to protect the important role of the community, it may have seemed to be doing so in a manner that ensured antidiscrimination and even racial integration of the legal process. But "antidiscrimination" and integration principles are not the appropriate norms for addressing a legal regime affecting Indians in Indian country. The underlying justification for a separate Indian country regime is preservation of the tribal right to remain separate and to avoid integration. ${ }^{245}$ In other words, discrimination, or at least separatism, is a positive normative principle in Indian law, not a negative one, and not one in favor of Indians as a race but in favor of tribes as distinct political organizations that have a right to continue to exist and exercise self-governance and self-determination. ${ }^{246}$ In that sense, the litigants and courts should look to the deeper intention of Duren $v$. Missouri, which was to ensure that a community is well-represented in its criminal justice regime. ${ }^{247}$

To frame the overarching problem in a slightly different way, jury panels in federal Indian country cases are not underinclusive because they fail to include adequate numbers of Native Americans but rather overinclusive because they include persons who do not live in Indian country and are not routinely subject to federal Indian country jurisdiction. The composition of Indian country juries is thus akin in the non-Indian context to using a statewide jury pool to adjudicate a local crime. Not only is such an approach difficult to justify as matter of criminal justice practice, it would violate state constitutions in many states. ${ }^{248}$ A proper analysis thus involves a more careful and explicit examination of the word "community."

The "fair cross-section of the community" rhetoric grows from the Sixth Amendment's interest in creating an "impartial jury." Federal courts have tended to construe "community" as the entire judicial district in which the offense occurred or as a division, which is a smaller subunit of the district. ${ }^{249}$ In other contexts, the Supreme Court has recognized that defining commu-

244. See Duren v. Missouri, 439 U.S. 357, 365-66 (1979).

245. Reservations exist in the United States to preserve for Indians and Indian tribes a right to what Professor Wilkinson has called a "measured separatism," a sanctuary where they are shielded from the authority of state actors. Charles F. Wilkinson, American Indians, Time, and the Law: Native Societies in a MOdern Constitutional Democracy 113 (1987).

246. See, e.g., Rice v. Cayetano, 528 U.S. 495 (2000); United States v. Antelope, 430 U.S. 641, 646 (1977); Morton v. Mancari, 417 U.S. 535 (1974).

247. See supra note 160.

248. Brian C. Kalt, Crossing Eight Mile: Juries of the Vicinage and County-Line Criminal Buffer Statutes, 80 WASH. L. Rev. 271, 272-333 (2005) (discussing state common-law principles and state constitutional provisions on trials by jury of the vicinage).

249. See, e.g., Jeffers v. United States, 451 F. Supp. 1338 (N.D. Ind. 1978) (holding that the term "community" is a term of art that refers to the total populace of the district or division where the court convenes). The Jury Selection and Service Act implicitly assumes such a construction. See 28 U.S.C. § $1869(\mathrm{e})(2000)$. 
nity is, to some degree, an exercise in existentialism: "[c]ommunities differ at different times and places." ${ }^{\text {,250 }}$ But rather than creating fair cross-sections of the communities served by and subject to the Indian country legal regime, the courts have ensured only that the federal juries represent cross-sections of far different communities.

In future cases, defendants should make the straightforward argument that jurors in Indian country cases cannot be drawn from addresses outside Indian country because "Indian country" is the community that the law is designed to protect.

Even under the crabbed approach that the Eighth, Ninth, and Tenth Circuits have used in construing Duren, Indian country defendants ought to be able to make better arguments than they have presented in past cases. Indian defendants have made a critical error in presenting to the court statistics describing the entire district or division in which the court sits. The language of Duren recognizes that statewide figures are not always the relevant ones. ${ }^{251}$ While statistical numbers might be difficult to obtain, the community of reference for an Indian country case surely can be no greater than the geographical community that is subject to the Indian country laws. Thus, defendants and defense attorneys should begin their analyses with very different statistics than have been presented in the past. Specifically, the beginning point for demonstrating disparity should be the number of Indians within Indian country communities, for it is only these communities that are within the Indian country jurisdiction of the court. Given that Indians represent large majorities on Indian reservations, it should be easy to establish substantial absolute disparities and extremely large comparative disparities between their representation in the relevant population and their representation on jury venires and juries, especially in jurisdictions that hold trials in locations at great distances from the Indian reservations.

To evaluate this argument in a real context, consider the federal district of Arizona. Arizona's federal judicial district is divided into three divisions, the Prescott Division, the Phoenix Division, and the Tucson Division. Offenses arising in the Prescott Division are, theoretically, set for trial in the Prescott Division. And jurors for trials in the Prescott Division are drawn from the five northern Arizona counties that make up the Prescott Division. The Arizona portion of the Navajo Nation lies wholly within the Prescott Division and, according to the 2000 Census, has a little more than 100,000 people. ${ }^{252} \mathrm{~A}$ county-by-county survey of the five counties that make up the

250. Taylor v. Louisiana, 419 U.S. 522, 537 (1975).

251. Duren seems to concede that the community of reference is "this community," that is, the one in which the crime occurred. See Duren v. Missouri, 439 U.S. 357, 365-66 (1979). It further looked to the statistical data for Jackson County, which represents the jurisdiction of the state district court in that case. Id.

252. The actual number was 104,565. See U.S. Census Bureau, Profile of Selected Economic Characteristics: 2000: Geographic Area: Navajo Nation Reservation and OffReSERvation TRUST LAND (AZ PART) 3 (2000), available at http://www.indianaffairs.state.az.us/ tribes/Navajo.pdf. 
Prescott Division reveals that the Division, as a whole, encompasses almost 650,000 people. ${ }^{253}$

Figure 3

Arizona Indian Reservations and District Court Venues

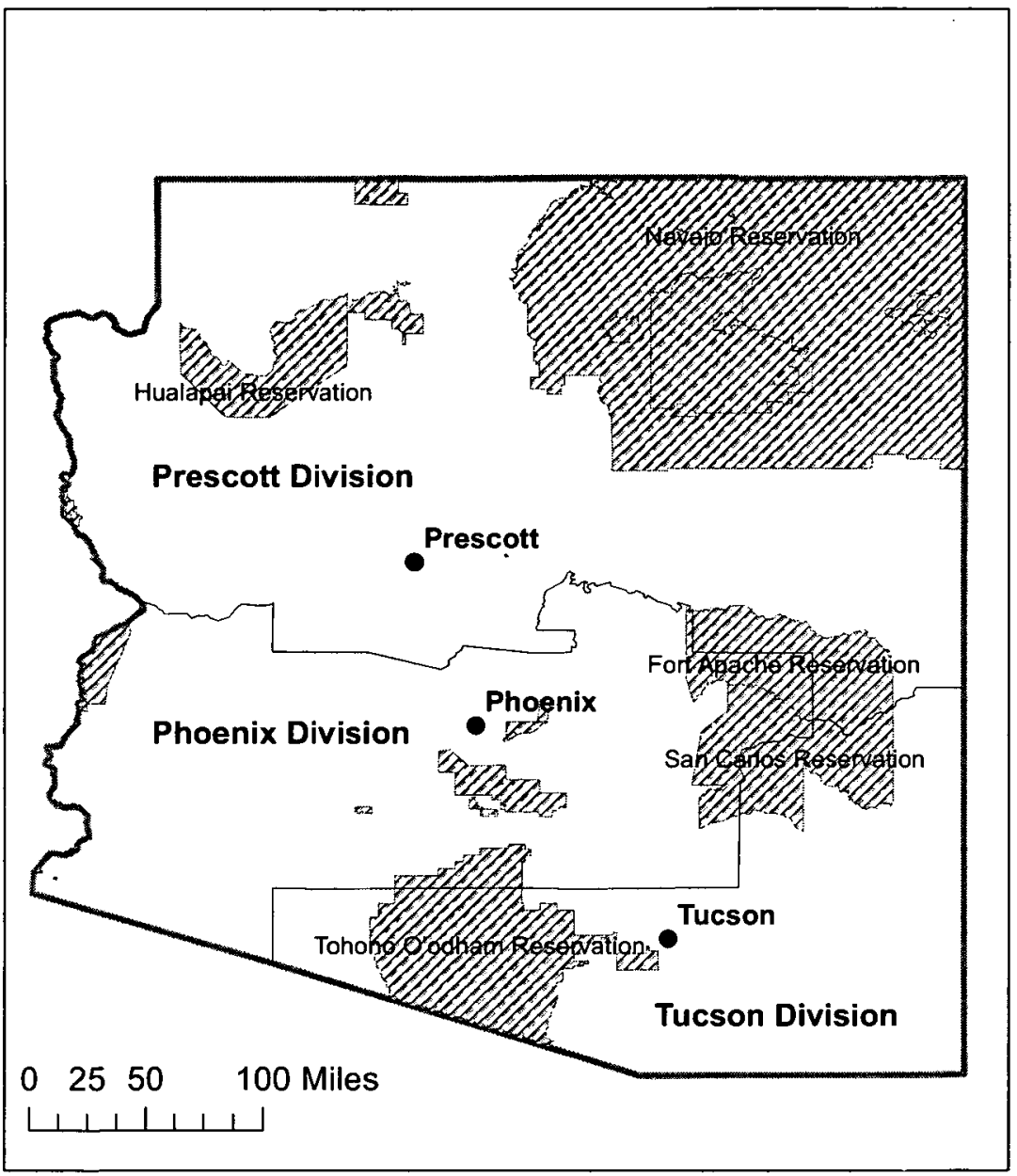

Even assuming that Navajo reservation residents were as well represented as those outside the reservation in the country rolls used to construct the jury pool, the average jury would be composed of jurors drawn overwhelmingly from outside Indian country. As a result, the Indian country

253. See U.S. District Court, District of Arizona, Frequently Asked Questions (Aug. 8, 2005), http:/www.azd.uscourts.gov/azd/courtinfo.nsf/court/faqs?opendocument; Arizona State \& County QuickFacts, http://quickfacts.census.gov.qfd/states/04000.html (last visited Sep. 5, 2005). 
community is only weakly represented, if at all, in the jury pool. As a practical matter, jury trials that are originally set for trial in Prescott are quite often moved to Phoenix, which draws its jurors from the Phoenix Division. The Phoenix Division has a smaller Indian country land base and an enormous metropolitan population, almost all of which is outside of Indian country. Based on the demographic numbers alone, it is likely that most juries hearing Indian country cases in Phoenix lack a single Indian country resident. Such a jury simply cannot be fairly said to "represent" that community.

The moral force behind the principle of community representativeness is strong and, perhaps ironically, even the Navajo Nation tribal courts have adopted it. ${ }^{254}$ In Navajo Nation v. MacDonald, the Navajo Nation Supreme Court affirmed a jury selection process in which a tribal court clerk created the jury venire by selecting names from the Navajo Nation voter rolls (all of which are tribal members) and also selecting a series of names that did not appear to be Navajo from the county voter registration rolls (which might well include tribal members, or nonmember Indians or non-Indians). ${ }^{255}$

The Navajo Nation Supreme Court recognized that tribal courts have unique problems selecting juries under such an approach; non-Indians may not feel compelled to appear when summoned for tribal jury duty. ${ }^{256}$ Moreover, the Navajo Nation Supreme Court's adoption of the fair cross-section requirement does not appear to be compelled by the federal Indian Civil Rights Act. ${ }^{257}$ Indeed, although that Act guarantees right to a jury trial that is in other respects somewhat broader than the right to jury trial set forth in the federal Constitution, ${ }^{258}$ the statute actually omits the requirement for an "impartial" jury, which is the constitutional hook for the "fair cross-section" requirement. ${ }^{259}$ The intentional omission of the requirement of an "impartial" jury may well have been intended to prevent tribal courts from being forced to go outside their own membership rolls to find jurors. In other words, the Navajo Nation courts provide a "fair cross-section" right to defendants of the tribe's own accord even though it is not required by federal law. This is some indication of the esteem in which the tribal jurisdiction with the single largest swath of Indian country feels about the principle, a fact that ought to be relevant to federal policymakers.

254. See 25 U.S.C. $§ 1302(2000)$.

255. Navajo Nation v. MacDonald, N.L.R. Supp. 285 (Navajo 1991).

256. Id. at 286.

257. 25 U.S.C. $\$ 1302$.

258. See 25 U.S.C. $\S 1302(10)$. This Act requires tribes to provide juries to anyone accused of an offense punishable by imprisonment. The federal Constitution only recognizes such a right for persons subject to a term of imprisonment for "serious offenses," which primarily refers to non-petty offenses, or those offenses which carry a prison term of greater than six months. See Duncan v. Louisiana, 391 U.S. 145, 159 (1968); Cheff v. Schnackenberg, 384 U.S. 373 (1966).

259. As is its style, the Navajo Nation Supreme Court did not acknowledge the Indian Civil Rights Act in its opinion and chose to apply the principle on its own accord. MacDonald, N.L.R. Supp 285 (Navajo 1991). 
In short, federal courts have erred in construing the relevant community as the entire judicial district, rather than considering which community the law seeks to protect. The Major Crimes Act and General Crime Act apply only within "Indian country" as that space is carefully defined in the United States Code. ${ }^{260}$ Indian country is an area in which the primary local governmental entity-the Indian tribe-has been stripped of its own authority to prosecute and adjudicate felony offenses. Against this backdrop, these laws thus provide courts with clear direction as to which community these laws are designed to protect. While the word "community" may be ambiguous in the Sixth Amendment, in the JSSA, and even in Supreme Court doctrine, any ambiguity about the word in the Indian country context is erased by the explicit definitions of Indian country in federal law. Indeed, the federal district courts would lack jurisdiction to prosecute most Indian country cases crimes if they had not arisen in Indian country.

The crimes enumerated in the Major Crimes Act are serious but routine offenses of a local nature with significant local effects and few effects beyond the locality. Yet most federal juries are unlikely to include a single representative from the local Indian community where the offense occurred and likely will not even include a single person who lives within Indian country. If the Sixth Amendment's requirement of a jury that is fairly representative of the community arises from the theory that the jury exists to ensure that the affected community plays a role in the provision of criminal justice within that community, ${ }^{261}$ then these purposes fail miserably in Indian country prosecutions. Because a federal jury is not composed of members of Indian reservation communities, it cannot claim to represent the Indian communities where major crimes occur. Thus, such juries do not ensure the legitimacy of criminal verdicts.

\section{Practical Effects of These Errors}

While such convictions are thus illegitimate as a formal matter, serious pragmatic ramifications follow from the errors in composing federal juries.

First, actual substantive errors may well creep into verdicts. Substantive criminal law is replete with statutory language that calls for interpretations of language by the local community, through the jury, in adjudicating crime. For example, some crimes and defenses hinge on whether an action or perception was "reasonable.", The word "reasonable" is inherently subject to context and cultural norms. It is, to a large degree, an empty vessel that

260. 18 U.S.C. $\$ 1151(2000)$.

261. See Massaro, supra note 146, at 546 ("One function of the jury, although not the only function, is to satisfy a community-centered interest in participation in the justice system by injecting representative community voices and values into the decision process.").

262. For example, the doctrine of self-defense uses the concept of reasonableness in numerous contexts. A common statement of the rule of self-defense, for example, is that one is privileged to use "reasonable" force against an adversary if one "reasonably" believes that he is in danger and that such force is necessary to avoid the danger. WAYNE R. LAFAvE, Criminal LAW $\S 10.4$ (4th ed. 2003). 
lawmakers and courts intentionally leave empty to be filled by jurors in any given case. In other words, the jury is the carrier of cultural norms of what is reasonable in any given community. A jury that is not representative of the community may well provide the wrong definition of the word "reasonable," and thereby reach an erroneous verdict. Given the open texture inherent in language and the peculiar role of juries in providing meaning in different contexts, it is possible for such errors to occur in a variety of contexts in criminal adjudications.

Second, consider a practical, but even more fundamental problem. The impact and the importance of any single criminal conviction lies in its broader meaning. Each conviction derives its normative force from what criminal law theorist Henry Hart called the "moral condemnation of the community." ${ }^{263}$ Indeed, expression of the moral condemnation of the community is one of the most profound purposes of the criminal justice system. Since, in Indian country cases, the defendant's community is absent, a convicted Indian country defendant is not likely to feel the weight of the condemnation of his own community. He is thus much less likely to feel the moral weight of the verdict. That weight, which causes the defendant to feel shame, is a powerful force driving the rehabilitative effects of criminal justice. ${ }^{264}$ Absent shame, one of the core purposes of punishment will not be met.

Jurors from outside Indian country may be in some senses "impartial" as jurors, but they may very well be entirely uninterested. While such a jury might be able to perform adequately the simple task of measuring the evidence against an objective legal standard, we use juries for much more sophisticated reasons. After all, a judge could perform the same task and yet the Supreme Court has repeatedly said that a judge is not adequate to the task. ${ }^{265}$ A jury not representative of the community is no better than a judge ${ }^{266}$ It cannot be said to be serving any of the other important values that the Supreme Court has discussed in dozens of cases cited above. Such a jury is not "representative of the community" or "fairly representative of the local population" as Taylor v. Louisiana ${ }^{267}$ says a jury must be. ${ }^{268}$

263. Henry M. Hart, Jr., The Aims of the Criminal Law, Law \& Contemp. Probs., Summer 1958 , at 401,406 (1958).

264. Toni M. Massaro, Shame, Culture, and American Criminal Law, 89 Mich. L. Rev. 1880 , 1901 (1991) (describing the sheer power of the emotion of shame which "strikes at the center of human personality" and "forces a downward redefinition of oneself"). To perhaps oversimplify, Professor Massaro is critical of modern efforts to leverage the shaming capabilities of criminal law precisely because shame is too powerful to be used in a humane manner. It is inherent in every criminal case.

265. See Apprendi v. New Jersey, 530 U.S. 466 (2000).

266. And the ramifications are real. A judge sitting as a finder of fact in a bench trial decides cases differently than a jury. See Barry C. Feld, The Constitutional Tension Between Apprendi and McKeiver: Sentence Enhancements Based on Delinquency Convictions and the Quality of Justice in Juvenile Courts, 38 WAKE Forest L. REv. 1111, 1161-69 (2003).

267. 419 U.S. 522, 537-38 (1975).

268. In Holland v. Illinois, 493 U.S. 474, 483 (1990), Justice Scalia, writing for the Court, noted that though the jury panel or venire must be representative of the community, it is to be ex- 
We might also question whether such juries are actually impartial. $\mathrm{Ka}$ gama's admonition that citizens of the states in which the Indian reservations are located are "often [the Indians'] deadliest enemies" ${ }^{, 69}$ may seem archaic and obsolete. ${ }^{270}$ But while the relative "deadliness" of state citizens undoubtedly has declined to some degree since the Major Crimes Act was enacted in the 1880 s, state citizens may not have the Indian country communities' best interests at heart. Racism and bias remain strong, particularly in states where Indians compete with non-Indians for limited resources. ${ }^{271}$ Accordingly, juries drawn broadly from outside Indian reservations may not be "impartial" when an Indian is a defendant. ${ }^{272}$

In summary, the regular federal jury selection process simply does not allow the jury to serve its fundamental purpose in Indian country cases. These juries are not representative of the community that is targeted or affected by the federal Indian country criminal justice regime. Neither Congress nor the courts have ever addressed this fundamental incoherence in the composition of juries in the Indian country criminal justice system. Because the jury's chief importance in American criminal justice is to give the community a role and because that role is crucial to the system's legitimacy, the verdicts produced through the existing jury process are not legitimate. The legacy of colonization is present in each of them.

\section{Public Access, Venue, and Public Trials}

Closely related to the jury composition problems in Indian country cases is a related set of issues in the constitutional doctrines of publicity and venue. While jury composition principles address which community decides

pected that representativeness will be diminished through peremptory strikes as the panel is reduced to an actual jury. Though representativeness will inevitably decrease, the jury's ability to judge the case impartially will increase. $I d$.

269. United States v. Kagama, 118 U.S. 375, 384 (1886).

270. All Indians now have a right to be state citizens and to vote in state elections. Indian Citizenship Act of 1924, Pub. L. No. 68-175, 43 Stat. 253 (1924) (now codified as part of 8 U.S.C. $\S 1401)$.

271. Thomas Biolsi, "Deadliest Enemies": Law and the Making of Race Relations ON ANd OfF Rosebud Reservation 2 (2001) (surveying the circumstances in South Dakota and finding "antagonism between reservation Indians and the surmunding populations does persist"); see Clinton, supra note 20 , at $521 \mathrm{n.88}$; (asserting that juries in communities immediately adjacent to Indian reservations are likely to be more hostile to an Indian defendant, due to common racial prejudice, than a federal jury drawn from a broader cross-section of the population); Bryan $\mathrm{H}$. Wildenthal, Fighting the Lone Wolf Mentality: Twenty-First Century Reflections on the Paradoxical State of American Indian Law, 38 Tulsa L. Rev. 113, 145 (2002) (noting that the statement in Kagama "is still true to some extent"); see also King, supra note 167, at 77 ("[J]urors, like all of us, are influenced by stereotypes about racial groups and members of racial groups. Negative racial stereotypes produce a 'reverse halo effect': members of negatively stereotyped groups are assumed to possess negative traits, and positive information about them is devalued."); $c f$. Arizona v. San Carlos Apache Tribe of Ariz., 463 U.S. 545, 566-67 (1983) (recognizing that there is "a good deal of force," to the argument that "[s]tate courts may be inhospitable to Indian rights"). See generally Elizabeth CoOK-Lynn, ANTI-Indianism in Modern America (2001).

272. Zuni Cruz, supra note 42, at 2148 (citing "the prejudices of the jury pool" as one of the problems in a trial for a Navajo defendant being tried in state court for an off-reservation offense). 
a case by focusing on which community comprises the jury, the venue provisions address which community hosts the trial.

In recent years, transfers of venue in several high profile cases, including the trial of the Los Angeles police officers who beat Rodney King and the New York City police officers who killed Amadou Diallo, have been the subject of scathing academic and public commentary. ${ }^{273}$ Such transfers raise concerns not only with regard to the racial composition of the juries in the new venue of transfer, but also a more serious problem-the preclusion of the affected community from participating in and witnessing the trial. But while the King and Diallo trials were extraordinary and received tremendous public attention, Indian country trials are always handled outside of Indian country. Thus, all Indian country cases are subject to the same basic flaws that spawned extensive criticism in these two extraordinary cases.

This Part will address two types of issues that merit concerns for both defendants and communities in every Indian country case. First, it will discuss the defendant's and the public's right to access the trial. It will then

273. For criticism of the venue transfer decision in the King case, see Erwin Chemerinsky, How Could the King Jury Do That?, Legal Times, May 11, 1992, at 23 ("However wellintentioned, the decision to change venue was highly questionable. The shift from Los Angeles to Simi Valley produced a significantly different demographic composition for the jury pool. Los Angeles is ethnically and economically diverse. Simi Valley is virtually all white and suburban."); David P. Leonard, Different Worlds, Different Realities, 34 LoY. L.A. L. REV. 863, 883 (2001) ("Had the case been tried in central Los Angeles, before a jury comprised, at least in part, of poor African Americans or others with similar life experiences, the defense argument that the police were reacting to a combative, potentially dangerous suspect almost certainly would have fallen on deaf ears. It would not have been difficult for jurors chosen from an inner city community to believe what their eyes were telling them - that the police officers brutally and unnecessarily beat an African American man who had committed no serious crime."); David Margolick, Switching Case to White Suburb May Have Decided Outcome, N.Y. TIMEs, May 1, 1992, at A20 ("In fact, however, the outcome of the case may well have been decided when Judge Stanley Weisberg of California Superior Court transferred the case from the city to Simi Valley, an overwhelmingly white, conservative enclave that is the home of the Ronald Reagan Presidential Library.'); Marvin Zalman \& Maurisa Gates, Rethinking Venue in Light of the "Rodney King" Case: An Interest Analysis, 41 ClEv. ST. L. REv. 215, 216 (2003) ("Soon after the verdict some legal observers suggested that an earlier decision to order a change of venue from urban Los Angeles to the suburban community of Simi Valley was the critical feature in the acquittal." (footnote omitted)). Similar disapproval surrounded the Diallo case in 1999. See Engel, supra note 149, at 1665 ("Recognizing that Los Angeles jurors are not Simi Valley jurors, nor Albany jurors Bronx jurors, leads to the conclusion that, before transferring a case, courts first must try to solve the problem of prejudice against the defendant in the original venue."); Josh Getlin, Cop Trial's Move Roils New York, L.A. TIMEs, Dec. 27, 1999, at Al ("Judges 'made demographics destiny,' said Newfield, suggesting the court should have tried to find impartial jurors before moving the case. Now, he said, "they have put New York on a path toward Simi Valley and Rodney King."'); Bob Herbert, Editorial, A Whitewash in Albany, N.Y. Times, Dec. 27, 1999, at A23, ("The problem is that the five Appellate Division judges who ordered the change of venue went out of their way to shift the case to an almost lily-white comfort zone for the officers. The judges stomped all over the appearance of fairness when they deliberately placed the case out of the reach of black New Yorkers, who the judges seem to feel are by reason of their color incapable of considering the evidence in the case and rendering a fair verdict."); Editorial, The Wrong Venue, N.Y. TimeS, Dec. 18, 1999, at A22 ("The decision by a state appellate court to move the criminal trial of four New York City police officers charged with the killing of Amadou Diallo to Albany County seems unjustified. The accused officers are presumed innocent and deserve a fair and impartial trial, but there is no evidence that the people of the Bronx and New York City cannot be trusted with this trial. Moving the trial to Albany, a predominantly white area, could lessen the respect with which many residents of New York City view the verdict."). 
discuss the issue of location of the trial, including the venue provisions and the implicit constitutional principle of vicinage. ${ }^{274}$

\section{A. Rights of Public Access to Criminal Trials}

Public access or publicity for criminal trials is guaranteed by two separate constitutional provisions. The Sixth Amendment protects the defendant's right to a public trial on the theory that the public will provide safeguards to corruption or oppression by government officials. The First Amendment creates a constitutional right of access to criminal trials for general members of the public who are not parties to the case. ${ }^{275}$ The Supreme Court has repeatedly emphasized the importance of public access in criminal trials. While the federal Indian country criminal justice regime may pose few formal barriers to public access, the regime creates substantial de facto barriers that prohibit meaningful public access to criminal trials and thus may violate the constitutional rights of both the defendant and the Indian country community.

\section{The Source and Rationale for the Right to Public Trials and Public Access}

The Sixth Amendment explicitly guarantees the defendant's right to a public trial: "In all criminal prosecutions, the accused shall enjoy the right to a speedy and public trial ...."276 This provision protects the defendant in myriad ways. First and foremost, it "has always been recognized as a safeguard against any attempt to employ our courts as instruments of persecution., ${ }^{277}$ According to the Court, "contemporaneous review [of judicial action] in the court of public opinion is an effective restraint on possible abuse of judicial power., ${ }^{, 278}$ Open proceedings—and publicity-also improve the quality of justice that the defendant receives by encouraging witness honesty and conscientiousness and sometimes providing an opportunity for unknown witnesses to come forward. ${ }^{279}$

However, the defendant is not the only player in the criminal justice scheme with important interests protected by public access. While the Supreme Court has refused to hold that the defendant's Sixth Amendment right protects the public, ${ }^{280}$ in Richmond Newspapers, Inc. v. Virginia, ${ }^{281}$ the Court

274. For those not familiar with the term, vicinage means simply "neighborhood." It is associated with a right at common law to be tried within the neighborhood or county where the crime occurred. See Black's LAW DictionaRY 1567 (6th ed. 1990).

275. Globe Newspaper Co. v. Super. Ct., 457 U.S. 596, 603 (1982).

276. U.S. CoNST. amend VI.

277. Gannett Co. v. DePasquale, 443 U.S. 368, 380 (1979) (quoting In re Oliver, 333 U.S. $257,270(1948))$.

278. In re Oliver, 333 U.S. at 270-71.

279. Gannett Co., 443 U.S. at 383.

280. See id. at 383-84.

281. 448 U.S. 555 (1980). 
did recognize a right emanating from the First Amendment that protects the public's right of access to criminal trials. As a result, a First Amendment right, possessed not by the defendant but by the public, has an equally significant role and also serves many important purposes. Cumulatively, the cases dealing with the defendant's Sixth Amendment public trial rights and the public's First Amendment rights to open access to trials produce literally dozens of justifications for the important role that public access plays.

Some justifications are as broad as the usual justifications for open government: public scrutiny has beneficial effects for any governmental function, ${ }^{282}$ and the public must be able to see the government's work to evaluate it. ${ }^{283}$

Many of the justifications are highly specific to the criminal trial process. The right of public access is often justified, for example, by utilitarian philosophy about the operation of the justice system. The Supreme Court has held that "public access to criminal trials... is essential to the proper functioning of the criminal justice system., ${ }^{284}$ The Court has cited the writings of Hale and Blackstone and cited approvingly of Jeremy Bentham's recognition that, beginning centuries ago, "open proceedings enhanced the performance of all involved, protected the judge from imputations of dishonesty, and served to educate the public."

Some of the justifications are not merely utilitarian, but normative: "[P]ublic proceedings vindicate the concerns of the victims and the community in knowing that offenders are being brought to account for their criminal conduct ...." ${ }^{286}$ The public has a "definite and concrete interest in seeing that justice is swiftly and fairly administered." ${ }^{287}$ And some of the justifications are both utilitarian and normative. The Court has borrowed from Bentham the notion that trials have "significant community therapeutic value" that is served only with open access to trials:

When a shocking crime occurs, a community reaction of outrage and public protest often follows. Thereafter the open processes of justice serve an important prophylactic purpose, providing an outlet for community concern, hostility, and emotion.... The crucial prophylactic aspects of the administration of justice cannot function in the dark; no community catharsis can occur if justice is done in a corner or in a covert manner. [And] results alone will not satiate the natural community desire for "satisfaction." A result considered untoward may undermine public confidence, and

282. Gannett Co., 443 U.S. at 412 (Blackmun, J., dissenting).

283. See Press-Enterprise Co. v. Super. Ct. of Cal., 464 U.S. 501, 507 (1984) [hereinafter Press-Enterprise I]; see also Press-Enterprise Co. v. Super. Ct. of Cal., 478 U.S. 1, 19 (1986) (Stevens J., dissenting) [hereinafter Press-Enterprise II]; Globe Newspaper Co. v. Super. Ct., 457 U.S. 596, 604 (1982) (finding a First Amendment right of access to criminal trials designed to protect free discussion of government affairs).

284. Press-Enterprise II, 478 U.S. at 12.

285. Richmond Newspapers, 448 U.S. at 569 \& n.7.

286. Id. at 509 .

287. Gannett Co., 443 U.S. at 383. 
where the trial has been concealed from public view an unexpected outcome can cause a reaction that the system at best has failed and at worst has been corrupted. ${ }^{288}$

The Court has also explained that without access, the community will not understand the system in general or its particular workings in a specific case, and it is difficult for a community to accept what it cannot observe. ${ }^{289}$

In sum, the First and Sixth Amendments protect different sorts of interests. Whether viewed from the public's perspective or the defendant's, however, public access is fundamental to the purposes of criminal trials. Without it, the defendant is denied key safeguards and the community is denied key participatory interests, not the least of which are peace of mind, catharsis, and closure. Without access to the trial by the interested community, neither the defendant's interests nor the public's interests are served.

\section{Public Access and Indian Country Defendants}

As explained above, trials for local offenses in Indian country routinely occur more than a hundred miles away from the communities where the crimes occurred..$^{290}$ In light of the tremendous distances, deep poverty, and other daily facts of life on Indian reservations, the defendants, their families, the victims, the witnesses, and other members of the community are often unable to attend criminal trials. ${ }^{291}$ While there may be no formal bar to access, the federal regime's removal of the trial from the community where the crime occurred to a distant city creates a routine, de facto denial of public access to trials.

Consider that witnesses who appear in federal court by subpoena are routinely reimbursed for travel expenses, provided hotel rooms, and paid witness fees, even though the law requires them to appear. ${ }^{292}$ In other words, though attendance is mandatory and absence is punishable by contempt proceedings, the federal government subsidizes their appearance. While such payments may well be necessary to vindicate the defendant's Fifth Amendment right to due process and Sixth Amendment right to present witnesses, such payments seem to concede that witnesses sometimes cannot appear

288. Richmond Newspapers, 448 U.S. at 569-571 (internal citations omitted, but citing, among others, JeREMy Bentham, Rationale of Judicial EvidenCE (1827)).

289. Id. at 572 .

290. See supra note 6 and accompanying text.

291. Admittedly, some of the same arguments might be made by any federal defendant in a large federal district. The federal districts with Indian country may be much larger than any federal districts that the Framers might have conceived of. Of the original colonies, even Virginia and New York are comparatively small by the standards of the Western and Midwestern states where Indian country jurisdiction exists. For most federal offenses, there is a legitimate national interest involved and the defendant's actions must affect national interests. Otherwise, presumably, there would be no federal jurisdiction. As noted above, however, Indian offenses are local in nature.

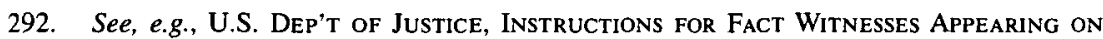
Behalf OF THE UNITED STATES GOVernMENT, Form OBD 2 (1996), available at http://www.usmarshals.gov/prisoner/obd2.pdf. 
without federal assistance. Given the poverty on Indian reservations, it is indisputable that members of the Indian community ordinarily might also be unable to attend federal criminal trials absent financial assistance.

Given that de facto denials of access to Indian country trials can be easily established, at least in some cases, the question is whether such circumstances constitute effective denial of the community's First Amendment right to public access. A compelling argument can be made that they do. While not all of the justifications for public access cited by the Court in recent cases require access by the affected community, ${ }^{293}$ most of the justifications require, or, at a minimum, will be better served by, the involvement of the specific community in which the crime occurred.

Consider first the defendant's right to a public trial as a criminal procedural safeguard. One stated justification for public trials is to ensure the "integrity and quality" of the testimony offered at trial ${ }^{294}$ and to encourage witnesses to perform their duties more conscientiously. ${ }^{295}$ Given those concerns, access by members of the affected community-friends and neighbors, in other words, rather than strangers-is likely to be much more effective in insuring witness conscientiousness and honesty. Practical experience suggests that it is harder to lie in front of friends than strangers. Indeed, the absence of any members of the relevant community in the gallery or on the jury may embolden a witness who is prone to lie or may at least allow the witness to be more careless with the facts. In such circumstances, the witness is not directly accountable to his own community for the testimony he provides. The witness's community may well be entirely unaware of the proceeding. At the same time, the cultural gulf may render the witness less invested in and less respectful of the federal criminal justice process. It is, of course, the defendant's own neighbors who are likely to be most concerned about any attempt to "employ [the] courts as instruments of persecution" has also justified public access on the expectation that publicity may "induce unknown witnesses to come forward with relevant testimony." 298

293. As long as the trial is open at least to some portion of the public, some of the "open government" purposes will be met. However, general members of the public cannot provide the safeguard against governmental misconduct that members of the Indian country community could provide. Community members are likely to have both a greater sense of the context of the government action and a keen incentive to conduct careful scrutiny; after all, it is their community that the crime has affected.

294. See, e.g., Richmond Newspapers, Inc. v. Virginia, 448 U.S. 555, 578 (1980).

295. Gannett Co. v. DePasquale, 443 U.S. 368, 383 (1979).

296. Id. at 380 (quoting In re Oliver, 333 U.S. 257, 270 (1948)).

297. One who believes in the right of jury nullification might recognize no opportunity for the Indian community to exercise the jury nullification power. See, e.g., Paul D. Butler, Race-Based Jury Nullification: Case-in-Chief, 30 J. Marshall L. Rev. 911, 912-13, 918-21 (1997) (arguing that minority jurors should exercise the power of jury nullification to overcome their marginalization as minorities in the political process and to serve as a political protest).

298. Gannett Co., 443 U.S. at 383. 
Certainly, this cannot be so unless the specific community in which the witnesses are located has easy access to the trial. ${ }^{299}$

\section{Public Access and Indian Country Communities}

Though the defendant's interests sometimes overlap with the community's, turn now from publicity as a safeguard to the defendant to consider the public's particular interests in open access. Consider for example the "community therapeutic" justification for public trials. Such a purpose simply cannot be served unless the affected community has access to the trial. No other community will do. It is the affected community that will have a "fundamental, natural yearning to see justice done.", community that might otherwise engage in "vengeful self-help",301 if it is not satisfied with the process or the outcome.

Indeed, this presents another cruel irony of the existing system. Federal officials originally justified their assertion of need for the Major Crimes Act at least partially on the concern that absent federal trials, there would be an unending cycle of violence because victims would naturally seek revenge and there was no tribal forum to resolve these disputes. ${ }^{302}$ Though that argument was dubious in context (tribes had methods of maintaining order that had worked for centuries and this particular offense had been addressed by the tribe in a traditional manner ${ }^{303}$ ), certainly one of the purposes for a criminal justice system is to address wrongs within formal channels to prevent informal efforts at revenge. But how can the criminal justice system serve this purpose if the relevant community is unaware of the criminal justice system's work? ${ }^{304}$ Indeed, if revenge is a serious concern, the existing system does not address it; acts of revenge might occur in Indian country because the community has no idea that "justice" has already been achieved.

Public access does not necessarily require actual members of the community in the courtroom. But since federal trials are not televised, they are

299. While this argument is being made in the context of trial, the requirement of public access also has been held to apply to other key stages of criminal proceedings. See, e.g., United States v. Alcantara, 396 F.3d 189 (2d Cir. 2005) (plea and sentencing hearings).

300. Richmond Newspapers, Inc. v. Virginia, 448 U.S. 555, 571 (1980).

301. Id.

302. See supra note 83 and accompanying text.

303. See generally Sidney L. Harring, Crow Dog's CASE (1994).

304. In this regard, the Indian country criminal justice regime ironically fails also to meet another of the key original purposes of the federal Major Crimes Act. One ostensible purpose of the Major Crimes Act to involve Indians in the American criminal justice system in an effort to "civilize" and assimilate them. In debate on the Act, one member of Congress repeatedly cited the Secretary of the Interior's arguments that such a law was needed for "civilizing the Indian race." 16 CONG. REC. 934 (1885) (statement of Rep. Cutcheon). While such a purpose might be explicitly disavowed in the current era, such a purpose could never have been served with trials held hundreds of miles from the Indian communities and without involvement from those communities. Such trials may have helped to "assimilate" the Indian defendant who was then convicted and served a term of imprisonment, but surely Congress did not mean to assimilate Indians one criminal defendant at a time. 
perhaps the least friendly forums for other forms of public access. In Indian country, it is likely that most tribal members are not even aware of distant federal criminal trials even while they are occurring. Few Indian country cases are covered in the popular press such as local television news programs or large daily newspapers. ${ }^{305}$ And while some local communities may have weekly or monthly newspapers that serve Indian country communities, ${ }^{306}$ few report on federal criminal trials.

To put the real world ramifications of an Indian country prosecution in the plain words of an Indian who served as a United States Attorney, the federal proceedings are practically meaningless to the Indian community: "five Indian defendants are arrested on the reservation for the assault and robbery and taken to federal court in Rapid City. Two of them eventually return to the reservation, but three of them don't come back; folks on the reservation don't really know why." ${ }^{307}$ As a result of this lack of understanding of the federal criminal process and the particular facts of individual trials, the existing system provides none of the of the "community therapeutic" benefits thought to be served by public trials.

The Supreme Court has repeatedly justified open access on the theory that it enhances not only basic fairness itself, but equally importantly, the appearance of fairness within the judicial system. ${ }^{308}$ Given that the Indian country criminal justice system has famously-and fairly-been characterized by legal scholars as a "jurisdictional maze,",309 it is fair to speculate that there may be fundamental parts of the system that are poorly understood by the average member of an Indian community.

The simplest way to convey the Supreme Court's "legitimacy" argument is to recognize that people are inherently suspicious of that which they do not understand. Like the proverbial tree that falls in the forest, does a trial that occurs hundreds of miles from the Indian community where the crime occurred reverberate with justice or fairness? By virtue of the federal courts' practical inaccessibility to the Indian community, federal Indian country criminal trials fail to educate Indian communities generally about the process of federal criminal law or specifically about the facts of individual cases. Absent involvement by the affected community, a trial cannot assure the

305. Kara Briggs et al., The Reading Red Report, Native Americans in the News: A 2002 Report and Content Analysis on Coverage by the Largest Newspapers in the United States (2002) (unpublished report), http://www.naja.com/resources/publications/2002_reading_red.pdf (finding a pattern of lack of coverage and uninformed coverage following a statistical analysis of the reportage in eight of the largest American newspapers about American Indians and tribes).

306. One example is the Gallup Independent which occasionally presents articles addressing Indian country criminal issues related to the Navajo Nation. See INDEP. (Gallup, N.M.), http://www.gallupindependent.com (last visited Nov. 13, 2005).

307. Discussion with Philip Hogen, former United States Attorney of South Dakota, Washington, D.C. (September 21, 2005).

308. Press-Enterprise I, 464 U.S. 501, 508 (1984).

309. Clinton, supra note 20; Richard W. Garnett, Once More into the Maze: United States v. Lopez, Tribal Self-Determination, and Federal Conspiracy Jurisdiction in Indian Country, 72 N.D. L. Rev. 433 (1996); William V. Vetter, A New Corridor for the Maze: Tribal Criminal Jurisdiction and Nonmember Indians, 17 AM. INDIAN L. REv. 349 (1992). 
legitimacy of the criminal justice system in general or the verdict issued in any given case.

Perhaps most importantly, federal Indian country trials undermine the most basic moral underpinnings of the criminal law. If a defendant does not feel the weight of moral judgment of his own community, he may not be confronted with his own actions in a way that would cause him to regret the actions that gave rise to his criminal offense. This harms both the defendant and the community and frustrates both the rehabilitative and retributive purposes of criminal law.

\section{Public Trials and Self-Government}

Jury trials and access to these trials by the general public are fundamentally designed to preserve public participation in government. In a lengthy concurrence in Press-Enterprise Co. v. Superior Court, Justice Stevens indicated that a primary mission of First Amendment was to secure meaningful public control over the process of governance. ${ }^{310} \mathrm{He}$ explained this mission in the context of public trials:

[T] he First Amendment serves to ensure that the individual citizen can effectively participate in and contribute to our republican form of selfgovernment... Our system of self-government assumes the existence of an informed citizenry.... It follows that a claim to access cannot succeed unless access makes a positive contribution to this process of selfgovernance. ${ }^{311}$

The words of Justice Stevens highlight the dissonance that exists in Indian country criminal justice. If the fundamental aim of the First Amendment protection of public access to criminal trials is to preserve the communities control over government, that is, its self-government, then Indians and Indian tribes have been wronged twice over. First, the Indian country criminal justice system displaced tribal governance over the most important criminal justice issues on the reservation. It then denied the Indian community the participatory rights that most other American communities have in their federal criminal justice system.

\section{B. Venue, Vicinage, and Place of Trial}

The Constitution addresses concerns similar to those outlined above in the venue provisions. The Constitution addresses the broad issue of venue by providing that criminal trials shall be held in the state in which the crime occurred. ${ }^{312}$ Though this mandate, in the past, was codified in federal law, ${ }^{313}$

310. Press-Enterprise I, 464 U.S. at 519 (Stevens, J., concurring).

311. Id. at 518-19 \& n.4 (Stevens, J., concurring) (citations and footnotes omitted).

312. U.S. Const. art. III, $\$ 2$.

313. See 28 U.S.C. $\S 1393$, repealed by Pub. L. 100-702, Title X, § 1001(a), 102 Stat. 4664 (1988). 
it is currently addressed in the rules of criminal procedure. Rule 18 of the Federal Rules of Criminal Procedure requires that generally "the government must prosecute an offense in a district where the offense was committed.,"314 It further requires the court to "set the place of trial within the district with due regard for the convenience of the defendant and the witnesses....,"315

The Sixth Amendment addresses a related but somewhat narrower concept of vicinage. It holds that the jury shall be drawn from the "State and district wherein the crime shall have been committed." ${ }^{316}$ According to Professor Akhil Amar, the narrow vicinage requirement in the Sixth Amendment arose directly from concerns by the Anti-Federalists who "wanted an explicit guarantee that juries would be organized around local rather than statewide communities." "institution of localism and popular sovereignty.",318

One reason for the narrow vicinage right was to ensure that the trial was "public" in every meaningful sense. In a world with far fewer media outlets than today's world, Professor Amar explains, "the public trial was designed to infuse public knowledge into the trial itself, and, in turn, to satisfy the public that truth had prevailed ...."319 The public trial was designed to ensure values of "democratic openness and education, public confidence, anticorruption, and truth seeking." $" 320$

Amar believes that the decision to use the word "district" rather than the common law term "vicinage" in the Sixth Amendment reflects a compromise by the founders to allow a political branch to make the ultimate decision. Thus, Congress would determine the scope of any "vicinage" right simply by defining judicial districts. ${ }^{321}$ Another commentator, Steven Engel, would go farther than Amar. Engel has argued that the vicinage presumption "inhered in the very notion of trial by jury" and was so fundamental to the common law legal tradition that the right to a jury of the vicinage did not need to be preserved explicitly. ${ }^{322}$ Engel highlights the adjudicative quality of the local jury, which is likely to be more familiar with the context of the crime and thus less likely to convict the innocent than a jury from a different

314. Fed. R. CRIM. P. 18.

315. Id.

316. U.S. Const. amend. VI.

317. AmAR, supra note 138, at 105.

318. Id. at 106.

319. Id. at 113.

320. Id.

321. While the right to a local jury was in some sense a safeguard for the defendant, it was not the most protective safeguard. That approach might have been, for example, to select a jury from his own home state. Thus, the "district" requirement represented a compromise between the competing interests of the defendant and the community in which the crime occurred. See AMAR, supra note 138, at 81-118; see also Massaro, supra note 146, at 508 (tracing the meaning of "district" in the Sixth Amendment).

322. Engel, supra note 149, at 1691. 
community. ${ }^{323} \mathrm{He}$ also vaunts the representative nature of the local jury, highlighting the jury's role as the "democratic branch" of the judiciary with the responsibility of "injecting the voice of the community into the administration of the laws." ${ }^{324}$ Finally, he notes the importance of the jury acting as the "voice" of the local community; as a result of the transfers of the King and Diallo trials, he argues, the juries in those cases had no claim to speak for the affected communities and thus the verdicts were not viewed as legitimate. ${ }^{325}$

Engel's argument for a vicinage right rests not just within the Sixth Amendment, but also within the First Amendment right of access cases discussed previously as well as cases, such as Powers v. Ohio, ${ }^{326}$ which recognize the right of individual jurors to serve on juries, or at least not to be arbitrarily excluded.

While Engel's argument that there is an implicit constitutional vicinage right is compelling, Indian defendants and communities do not need to convince courts to go nearly so far. Indian country communities need only to have courts recognize a much more modest vicinage right; that is, the vicinage right should be coextensive with the court's geographical jurisdiction. ${ }^{327}$ For Indian country offenses under the Major Crimes Act and the General Crimes Act, ${ }^{328}$ the geographical jurisdiction of the court extends only to Indian country.

Given the importance of the First and Sixth Amendments and the general importance of the jury in American criminal justice, the problems identified above strike at the core of the Indian country criminal justice system. Whether the legal argument is presented as a right to a public trial, public access, venue, or vicinage, trials in Indian country fail to square with fundamental constitutional values. As a result, Indian defendants and Indian communities are subjected to a federal criminal justice process that is of dubious constitutional and moral legitimacy.

323. Id. at $1693-95$.

324. Id. at 1696.

325. Id. at $1698-99$.

326. Powers v. Ohio, 499 U.S. 400,406 (1991) ("The opportunity for ordinary citizens to participate in the administration of justice has long been recognized as one of the principal justifications for retaining the jury system.").

327. Even if Amar's view is correct that any constitutional vicinage right is limited by Congress's definition of district, Congress has done a curious job of defining federal judicial districts. Consider that the State of Oklahoma is divided into three judicial districts while the State of Arizona, a much larger and more populous state, constitutes only one judicial district. The result is that jurors (as well as defendants, witnesses, or victims) in Oklahoma are, on average, far closer to the federal criminal trials that arise in their communities than jurors in Arizona. Such a regime poses a disparate burden on Indian communities in Arizona.

328. One remaining question is whether such reasoning could be extended to prosecutions in federal enclaves, such as military bases. In those circumstances, some of the arguments are equally compelling; however, those cases involve particular reasons for the federal jurisdiction that are fundamentally different than Indian reservations, and the background tribal sovereignty, the notion that there is a pre-existing sovereign that has been shunted aside, is absent. 


\section{A FramewORK FOR ANALYSIS OF REFORM}

The existing federal system has many flaws and some of these flaws are serious. Indeed, they strike at the very heart of the legitimacy of the system. The issues raised herein must be addressed if any meaningful reform of Indian country criminal justice is to occur. The framework for reform is, however, not obvious.

One could read the critical analysis set forth above and make a reasonable argument that the federal Indian country criminal justice system is not fatally flawed, but that it has strayed from its own guiding norms. Thus, one might "reform" the existing federal system simply by steering it back to its foundational norms and without otherwise looking outside that system.

Tremendous improvements might be achieved simply by applying existing federal norms more carefully and appropriately. For example, the prosecutorial function should be modified so that the prosecutor executes her responsibility in a manner consistent with the theoretical foundations for the exercise of prosecutorial power. Likewise, jury composition should proceed in accordance with the fundamental Sixth Amendment norm of community representativeness. It might well be possible to implement various relatively modest reforms to the existing system that would help the federal system achieve compliance with its own norms.

Working on an approach to fixing the federal system, however, is not necessarily the appropriate place to begin. A serious effort at reforming criminal justice in Indian country ought also to look outside the federal system. Put another way, the reform analysis ought to begin one step prior to evaluation and reform of the federal system. Such an effort might begin by asking whether the federal government is the proper governmental institution to provide law enforcement and criminal justice on Indian reservations. After all, the federal government is only one of the possible providers of criminal justice and public safety on Indian reservations.

In the United States today, there are three different providers of criminal justice in Indian country. In addition to the federal system, many tribal systems are involved in criminal justice, though their jurisdiction is limited to misdemeanors. ${ }^{329}$ And in some states (those in which Public Law 280 or similar laws prevail), state and local governments have criminal jurisdiction on Indian reservations. A careful focus on reform of criminal justice in Indian country would evaluate each of these three government-types and determine which is best suited to the important responsibility of Indian country criminal justice. Each of the three government types has advantages and disadvantages compared to the others.

For example, while the existing federal system has all of the problems set forth above (and more), state authority in this realm also poses some problems. Although the fundamental geographic and accountability issues posed by prosecutions by distant federal prosecutors might be mitigated by use of local state prosecutors, new problems might arise. Given that the 
federal system was justified by the notion that local state citizens were the tribe's "deadliest enemies," we might see serious pushback and concern by tribes in response to a proposal to turn criminal authority over to the states. The cavalry effect that afflicts federal prosecutors might simply be replaced by something even more pernicious. The problem of federal declination and underprosecution could well be exacerbated or might even morph into the opposite problem with an elected local prosecutor using aggressive prosecutions of Indians in some cases as a race-baiting appeal to the worst tendencies of majority white voters in rural districts. In other words, the political stakes in the outside community neighboring the reservation could have negative effects on criminal justice on the reservation. Yet, despite the problems related to federal and state prosecutors, real concerns might be raised in some quarters about giving tribes more power over criminal justice. To outsiders (and sometimes to insiders), tribal governments are sometimes viewed as being tugged in inappropriate directions by warring political factions and the reputations of tribal officials are sometimes tarnished by assertions of corruptibility. As a result, some might view the independence and lack of accountability of federal prosecutors as a distinct advantage that helps them, in most cases, to make charging decisions in a fairer and more objective fashion. As this analysis of the prosecutorial function illustrates, careful analysis for purposes of a reform agenda is a complex task.

Moreover, any such analysis should recognize that the solution may not involve a winner-take-all approach for the federal, state, or tribal governments. Because there are ways to split the criminal justice function between governments, it is important also to examine the respective roles that each government might play as to each institutional function. For example, the average Indian country case now involves federal prosecutors appearing before what amounts to state juries. And, through a self-government contract, an Indian tribe may well have provided the police investigative services used in the case. In essence, the existing scheme is often one of hybrid roles. It is important to recognize the fluidity of current allocations of power and to recognize the possibility that such a hybridized or shared jurisdictional approach might be more fruitful than seeking to place all functions within only one government.

In sum, a comprehensive analysis of reform must take a sober look at the three governmental options and must compare and contrast the utility of each in providing criminal justice in Indian country. In taking a hard look at key portions of the federal system as it currently operates in Indian country, this article has sought to begin that process.

\section{CONCLUSION}

The Constitution implicitly and explicitly recognizes that crime is a local problem and should be addressed by local institutions. Two of the key institutions of American criminal justice, prosecutor and juries, have been designed in such a way to execute this fundamental constitutional norm. 
Both prosecutors and juries, however, fail to meet their constitutionally envisioned responsibilities in federal Indian country cases, primarily because they do not embrace the Constitution's clear preference for local criminal justice solutions to local crime problems.

In most of the United States, addressing violent acts in criminal trials is an expressive community act. Indeed, most felony prosecutions in this country are conducted under the direct authority of prosecutors who are elected by the community they serve. Because the Indian country is dealt out of its criminal justice system, the process of criminal justice on Indian reservations is neither an affirmation of community mores nor a formalized expression of community outrage. To the local community, it is, at best, a hollow effort. At worst, it is simply another imposition of authority by a foreign government that does not even seriously intend to occupy the soil upon which it seeks to impose its will. It is a relic of the colonialist roots of the American criminal justice system.

The preference for local control in the American criminal justice system has animated the Constitution for more than two centuries, and that has been institutionalized in norms of American constitutional criminal procedure since shortly after the Civil War. It is perhaps ironic that this preference for local community control has a parallel in federal Indian policy. In the last three decades, Congressional Indian policy has adopted the rhetoric of "tribal self-determination." Local community representation in criminal justice and tribal self-determination in other areas of governance really are not that different. Indeed, the theories underlying local criminal justice and tribal self-determination spring from the same sources of liberal political philosophy and are designed to serve similar interests. Thus, while the denial of tribal self-determination has constitutional ramifications for a federal criminal justice system that denies local control of the key institutions of criminal justice, tribal self-determination may offer one possible route out of the existing morass.

If a fundamental principle of American governance and of criminal jurisprudence is that crime and criminal justice are local issues, then Indian communities deserve a far greater role in the criminal justice system that affects them. The United States Constitution may well demand it. 
